\title{
Evidence of elevation-specific growth changes of spruce, fir, and beech in European mixed mountain forests during the last three centuries
}

\author{
Hans Pretzsch, Torben Hilmers, Peter Biber, Admir Avdagić, Franz Binder, Andrej Bončina, \\ Michal Bosela, Laura Dobor, David I. Forrester, Mathieu Lévesque, Aida Ibrahimspahić, \\ Thomas A. Nagel, Miren del Río, Zuzana Sitkova, Gerhard Schütze, Branko Stajić, Dejan Stojanović, \\ Enno Uhl, Tzvetan Zlatanov, and Roberto Tognetti
}

\begin{abstract}
In Europe, mixed mountain forests, primarily comprised of Norway spruce (Picea abies (L.) Karst.), silver fir (Abies alba Mill.), and European beech (Fagus sylvatica L.), cover about $10 \times 10^{6}$ ha at elevations between $\sim 600$ and $1600 \mathrm{~m}$ a.s.1. These forests provide invaluable ecosystem services. However, the growth of these forests and the competition among their main species are expected to be strongly affected by climate warming. In this study, we analyzed the growth development of spruce, fir, and beech in moist mixed mountain forests in Europe over the last 300 years. Based on tree-ring analyses on long-term observational plots, we found for all three species (i) a nondecelerating, linear diameter growth trend spanning more than 300 years; (ii) increased growth levels and trends, the latter being particularly pronounced for fir and beech; and (iii) an elevation-dependent change of fir and beech growth. Whereas in the past, the growth was highest at lower elevations, today's growth is superior at higher elevations. This spatiotemporal pattern indicates significant changes in the growth and interspecific competition at the expense of spruce in mixed mountain forests. We discuss possible causes, consequences, and silvicultural implications of these distinct growth changes in mixed mountain forests.
\end{abstract}

Key words: climate change, competition shift, dominance of beech, growth trends, relative loss of Norway spruce.

Résumé : En Europe, les forêts mixtes de montagne, surtout composées d'épicéa commun (Picea abies (L.) Karst.), de sapin blanc (Abies alba Mill.) et de hêtre commun (Fagus sylvatica L.), couvrent $10 \times 10^{6}$ ha à des altitudes de $\sim 600$ à $1600 \mathrm{~m}$ ASL. Ces forêts fournissent de précieux services écosystémiques. Cependant, on s'attend à ce que la croissance de ces forêts et la compétition entre leurs principales espèces soient fortement perturbées par le réchauffement climatique. Dans cette étude, nous avons analysé l'évolution de la croissance de l'épicéa, du sapin et du hêtre dans les forêts mixtes humides de montagne en Europe au cours des 300 dernières années. Sur la base des analyses des cernes annuels des arbres dans des parcelles d'observation à long terme, nous avons noté chez les trois espèces (i) une croissance linéaire en diamètre qui ne ralentit pas s'étendant sur plus de 300 ans; (ii) une croissance plus élevée, particulièrement chez le sapin et le hêtre et (iii) un changement dans la croissance du sapin et du hêtre relié à l'altitude. Alors que dans le passé la croissance était plus forte à basse altitude, elle est maintenant plus forte à haute altitude. Cette configuration spatio-temporelle témoigne de changements dans la croissance et la compétition

Received 25 October 2019. Accepted 15 March 2020.

H. Pretzsch,* T. Hilmers, P. Biber, and G. Schütze. Chair of Forest Growth and Yield Science, Centre of Life and Food Sciences Weihenstephan, Technical University of Munich, Hans-Carl-Von-Carlowitz-Platz 2, 85354 Freising, Germany.

A. Avdagić and A. Ibrahimspahić. Chair of Forest Management and Urban Greenery, Faculty of Forestry, University of Sarajevo, Zagrebačka 20, 71000 Sarajevo, Bosnia and Herzegovina.

F. Binder. Bavarian State Institute of Forestry (LWF), Hans-Carl-von-Carlowitz-Platz 1, D-85354 Freising, Germany.

A. Bončina and T.A. Nagel. Department of Forestry and Renewable Forest Resources, Biotechnical Faculty, University of Ljubljana, Večna pot 83, 1000 Ljubljana, Slovenia.

M. Bosela. Faculty of Forestry, Technical University in Zvolen, Zvolen, Slovakia; National Forest Centre, Forest Research Institute Zvolen, T.G.Masaryka 22, 96001 Zvolen, Slovakia.

L. Dobor. Faculty of Forestry and Wood Sciences, Czech University of Life Sciences Prague, Kamýcká 129, 16521 Prague 6, Czech Republic.

D.I. Forrester. Swiss Federal Institute of Forest, Snow and Landscape Research WSL, Zürcherstrasse 111, 8903 Birmensdorf, Switzerland.

M. Lévesque. Forest Ecology, Department of Environmental Systems Science, ETH Zurich, Zurich, Switzerland.

M. del Río. INIA, Forest Research Centre, Crta. La Coruña km 7,5 28040 Madrid, Spain; Sustainable Forest Management Research Institute, University of Valladolid \& INIA, Spain.

Z. Sitkova. National Forest Centre, Forest Research Institute Zvolen, T.G.Masaryka 22, 96001 Zvolen, Slovakia.

B. Stajić. Faculty of Forestry, University of Belgrade, Kneza Višeslava 111030 Belgrade, Serbia.

D. Stojanović. Institute of Lowland Forestry and Environment, University of Novi Sad, Antona Čehova 13, 21000 Novi Sad, Serbia.

E. Uhl. Chair of Forest Growth and Yield Science, Centre of Life and Food Sciences Weihenstephan, Technical University of Munich, Hans-Carl-VonCarlowitz-Platz 2, 85354 Freising, Germany; Bavarian State Institute of Forestry (LWF), Hans-Carl-von-Carlowitz-Platz 1, D-85354 Freising, Germany.

T. Zlatanov. Institute of Biodiversity and Ecosystem Research, Bulgarian Academy of Sciences, 2 Gagarin Street, 1113 Sofia, Bulgaria.

R. Tognetti. Dipartimento di Agricoltura, Ambiente e Alimenti, Università degli Studi del Molise, Via Francesco De Sanctis, 86100, Campobasso, Italy. Corresponding author: Hans Pretzsch (email: hans.pretzsch@tum.de).

*Hans Pretzsch currently serves as an Associate Editor; peer review and editorial decisions regarding this manuscript were handled by Paolo Cherubini. Copyright remains with the author(s) or their institution(s). This work is licensed under a Creative Commons Attribution 4.0 International License (CC BY 4.0), which permits unrestricted use, distribution, and reproduction in any medium, provided the original author(s) and source are credited. 
interspécifique aux dépens de l'épicéa dans les forêts mixtes de montagne. Nous discutons des causes possibles, des conséquences et des implications sylvicoles de ces changements marqués dans la croissance des forêts mixtes de montagne. [Traduit par la Rédaction]

Mots-clés : changement climatique, changement dans la compétition, dominance du hêtre, tendances de la croissance, perte relative d'épicéa commun.

\section{Introduction}

In temperate Europe, mixed mountain forests of Norway spruce (Picea abies (L.) Karst.), silver fir (Abies alba Mill.), and European beech (Fagus sylvatica L.) connect the lowland beech forest communities with the spruce-dominated alpine forest types. Whereas forests in the lowlands were exploited much more intensively and were mostly converted to age-class systems by clear-cutting, forests located at higher elevations were often managed less intensively or were left in a more natural state compared with lowland forests (Magin 1959). The main reasons were that the productivity of mountain forests decreases with elevation, mountain forests are less accessible for logging, and mountain forests are highly relevant for protection against gravitational hazards such as avalanches, landslides, or rockfalls and other watershed services (Bebi et al. 2001).

We analyzed a species combination that covers an area of about $10 \times 10^{6}$ ha of mixed mountain forests in Europe (Hilmers et al. 2019). Norway spruce, silver fir, and European beech have coexisted for thousands of years in mixture without active management or with close-to-nature forestry across this region (Magin 1959; Preuhsler 1979). Although mixing proportions can favour one of the three species, in the long term, none of the three species are outcompeted. Here, we examine probable reasons for this balanced coexistence. We used increment records covering the last 300 years for revelation of the spatiotemporal growth response to changing environmental conditions. Based on the results, we will be better able to manage the balanced and successful interaction among the three species.

One precondition of a potential coexistence is the overlap of fundamental ecological niches among species (Hutchinson 1957). At elevations of $600-1600 \mathrm{~m}$ above sea level (a.s.1.), the climate envelopes of the three species intersect. Silver fir occurs with 500-1500 $\mathrm{mm}$ annual precipitation and $3-12{ }^{\circ} \mathrm{C}$ mean annual temperature, and European beech occurs with 450-1500 mm annual precipitation and $3-12.5{ }^{\circ} \mathrm{C}$ mean annual temperature; both species are present from the lowland to the montane zone where they are limited by temperature. Norway spruce is better adapted to a cold climate and occurs with $450-1250 \mathrm{~mm}$ annual precipitation and $-2.5-8.5{ }^{\circ} \mathrm{C}$ mean annual temperature (Kölling 2007).

Another precondition of coexistence is similar fitness (competitive ability) in the presence of competitors; this enables a common real niche. Similar light ecology across the species is an important feature in this context. All three species are shade tolerant, so none of them will be easily outshaded by the others in the long term. There is a ranking in light requirement, with spruce being more light demanding than fir and fir more than, or very similar, to beech, but the differences seem relatively small compared with tree species that demand more light such as Scots pine (Pinus sylvestris L.) or European larch (Larix decidua Mill.) (Valladares and Niinemets 2008). The minimal light requirements of shade leaves or needles in relation to light above canopy (100\%) amounts to $3 \%$ for Norway spruce, $1.5 \%$ for silver fir, and $1.0 \%$ for European beech (Ellenberg and Leuschner 2010, pp. 103-105). Other authors (Burschel and Huss 1987, p. 171; Mitscherlich 1971, p. 76) rank fir and beech even more equally, which underpins their similar light ecology.

Norway spruce has proven to be more drought susceptible than beech and fir (Zang et al. 2014), although spruce foliage is xeromorphic. Both spruce and fir conifers reflect an isohydric strategy
(Lyr et al. 1992), reducing stomata conductance at early stages of soil drought. Hence, xeromorphism of needles may be a feature to preserve water in the tree, once the stomata have closed. Under nonlimiting water supply, the lower leaf-level transpiration rate of spruce and fir is counteracted by higher leaf biomass and leaf area index at the stand level relative to beech (Ellenberg et al. 1986; Lyr et al. 1992). By contrast, beech displays an anisohydric strategy, with the stomata being less sensitive to soil drought, allowing for less limited carbon gain and stem and root growth during prolonged time spans under drought than in spruce and fir (Leuschner 2009; Nikolova et al. 2009). However, the hazardous behaviour of the anisohydric beech can be beneficial when water is abundant or under moderate drought stress, while leading to tree mortality under the impact of extreme water shortage (e.g., Klein 2014). Again, with increased atmospheric carbon dioxide $\left(\mathrm{CO}_{2}\right)$ concentration, the isohydric spruce and fir may limit risk of carbon starvation, following stomatal closure under drier conditions.

There are many more structural and functional traits such as crown plasticity (Jucker et al. 2015; Forrester and Albrecht 2014), rooting depth (Rothe 1997; Schmid and Kazda 2002), litter decomposition (Rothe and Binkley 2001), and browsing pressure (Ammer 1996) that prevent any one of the three species from becoming a permanent winner or loser, and despite their effects changing with climate and growing conditions, the balance among the tree species is maintained. That is, the potential damages are rather equally distributed, with the late frost and ozone susceptibility of fir and beech (Larsen et al. 1990; Matyssek et al. 2010), the high sensitivity to smoke damage and acid deposition of silver fir (Elling et al. 2009), and the high risk of bark beetle infestation (Wermelinger 2004) and snow and storm damage (Spiecker 2000) of Norway spruce. This temporal, spatial, and functional complementarity and risk distribution may contribute to the overyielding of Norway spruce and European beech (Pretzsch et al. 2010; Rothe 1997), Norway spruce and silver fir (Jensen 1983; Pretzsch et al. 2010; Vallet and Pérot 2011), and Norway spruce, silver fir, and European beech (Pretzsch and Forrester 2017; Mina et al. 2018).

Hilmers et al. (2019) found that in terms of stand growth, mixed mountain forest ecosystems are rather resilient against disturbances such as acid deposition, climate warming, and ozone. Increment losses of one species can be counteracted and compensated by the other species. However, acid deposition, late frost and ozone impact, or increasing frequencies of extreme drought events and bark beetle attacks can compromise the contribution of fir, beech, and spruce, respectively (Bircher et al. 2016; Lindner et al. 2010). So, external negative effects on one of the three species can weaken its competitive ability, change its functional role, and change its growth contribution in favour of the other two (Bosela et al. 2019; Hilmers et al. 2019).

Mixed mountain forests in Europe are severely exposed to warming temperatures with no significant changes in precipitation (Auer et al. 2007, Bircher et al. 2016). In addition, increasing natural disturbances such as windstorms or bark beetle outbreaks are to be expected (Seidl et al. 2017). Further changes in the climate system could fundamentally alter the composition and structure of mountain forests (e.g., because of climate-induced shifts in species' niches) (Hanewinkel et al. 2013; Thom et al. 2017; Obojes et al. 2018). Previous research has shown that climate warming has increased the growing season length and productiv- 
ity of mountain forests (Oberhuber 2004; Jolly et al. 2005), generally above the elevational zone where mixed forests occur. It is less clear how climate change will influence mixed-species forests below the high alpine zone. For example, if beech benefits from higher temperatures at elevations between 600 and $1000 \mathrm{~m}$, this may reduce the competitiveness of Norway spruce and silver fir. Any changes in the fitness and growth of one of the three species can be caused either directly by improved or reduced external growing conditions or indirectly by a strengthening or weakening of the competitors. Nonetheless, if water becomes increasingly limiting, the effects of climate change might become negative (Pichler and Oberhuber 2007; Allen et al. 2015).

Based on what is known about the three dominant tree species in mixed mountain forests, we can hypothesize how their relative growth may change across an elevation gradient in response to a changing climate. For example, Norway spruce may profit at the cold margin of its niche under increasing temperatures. In other words, areas at higher elevations where temperature was previously limiting may benefit Norway spruce more than European beech and silver fir, particularly when temperatures are still too cold for optimal growth of the latter two species. Based on the same reasoning, it follows that the smallest benefit for spruce should be at the lower elevations as temperature becomes suboptimal. At low elevations of the mixed mountain forest zone, the competitive pressure on Norway spruce may increase because of accelerating fir and beech growth and growth recovery of silver fir and European beech from sulfur dioxide $\left(\mathrm{SO}_{2}\right)$ pollution and ozone $\left(\mathrm{O}_{3}\right)$ damage, respectively (Elling et al. 2009; Uhl et al. 2013). The growth of silver fir and European beech at the higher elevations may also be enhanced by climate warming, especially on sites with sufficient water and nutrient supply and where temperature, late frost, and the length of the growing season were limiting their growth in the past.

We analyzed the growth changes of Norway spruce, silver fir, and European beech at 28 sites located across the European mountain regions. Climate warming in these regions is often coupled with sufficient water supply, but local variation in water supply and soil conditions may modify the general response pattern previously hypothesized. Based on the aforementioned considerations about elevational-dependent climate change effects in mixed mountain forests, we developed the following questions.

(i) How did the growth of the three tree species develop during the last three centuries?

(ii) Were there species-specific changes in the growth trends during this time period?

(iii) Were there elevational-dependent changes in the growth trends during the last three centuries?

\section{Materials and methods}

\subsection{Materials}

\subsubsection{Observational plots, site conditions, and sample sizes}

For the increment cores sampling, we selected 28 fully stocked, unthinned, or slightly thinned long-term research forest stands distributed across Europe (Fig. 1; Table 1). We included only fully stocked, unmanaged reference plots where growth was scarcely affected by human activities and that reflected natural dynamics and climate variations.

\subsubsection{Tree measurement protocol and core sampling}

Increment cores were collected from about 20 dominant trees of each species per plot. To avoid damaging the trees on the plots, we sampled in most cases in the buffer zone of the plots, which were also fully stocked, unthinned, or just slightly thinned.

We sampled only trees of Norway spruce, silver fir, and European beech. The stem diameter at breast height $(\mathrm{DBH}$; breast height $=1.3 \mathrm{~m}$; in millimetres) was measured using a tape, and the
Fig. 1. Location of the 28 observational plots (black dots) in mixed mountain forests of seven countries where increment cores of Norway spruce, silver fir, and European beech were sampled for this study. The study covered mountain forests in Bosnia and Herzegovina, Bulgaria, Germany, Serbia, Slovakia, and Switzerland. See Tables 1 and 3 for descriptions of plot data. Map layers were compiled using QGIS version 3.12.3 (QGIS Development Team 2020).

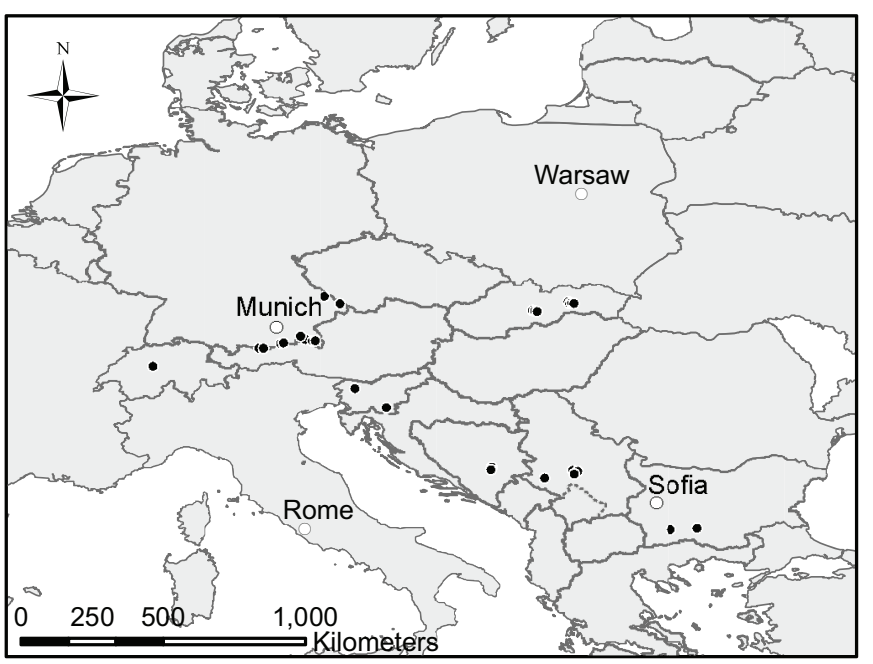

height and height to the crown base (in decimetres) were measured using a Vertex hypsometer (Haglöf Sweden $\mathrm{AB}$, Långsele, Sweden). The height to crown base was defined as the distance from the ground to the lowest living primary branch.

From each tree, we took two $5.15 \mathrm{~mm}$ cores at breast height, in the northern and eastern directions, with a standard increment borer, attempting to hit the centre of the stem to cover as many growth rings as possible. The increment cores were air-dried, mounted and glued on wooden supports, and subsequently sanded using sandpaper with progressively finer grit.

We applied a careful visual procedure for making sure that the sampled trees were not only dominant at the time of sampling, but also in the past. First, if longer suppression phases were clearly discernible on the wood sample immediately after coring in the field, the sample was not included in this study, and an alternative tree was selected. Second, after the growth ring widths were measured, we plotted the empirical growth curves for visual examination. About 5\% of the trees were excluded at that stage because their growth curves showed depression phases of 10 years or more.

We tried to reduce the potential sampling bias (Cherubini et al. 2002; Nehrbass-Ahles et al. 2014) by applying the following criteria when selecting the sample trees. Most of the trees were sampled on long-term observation plots, so that their growth and social position in the last 50-100 years were documented. Based on this documentation, we sampled only trees that were dominant throughout this observation time. We sampled only trees with crown ratios (crown length/tree height) $>0.5$, as long crowns indicate a probably continuous dominance of the trees in the past. To avoid sample trees with suppression phases in the more distant past, we excluded all trees with longer low-growth phases as described by Pretzsch (2009, pp. 587-588). Such low-growth phases were either already visible on the increment cores during the sampling procedure in the forest or became visible when plotting growth rates over age after ring analyses in the tree-ring laboratory.

\subsubsection{Tree-ring analyses and overview of tree-ring data}

Tree-ring widths were measured to the nearest hundredth of a millimetre using a digital positioning table (Kutschenreiter and 
Table 1. Geographical information and site characteristics of the 28 long-term observational plots.

\begin{tabular}{|c|c|c|c|c|c|c|c|}
\hline \multirow[b]{2}{*}{ Country } & \multirow[b]{2}{*}{ Plot code } & \multicolumn{2}{|l|}{ Coordinates } & \multicolumn{4}{|c|}{ Site characteristics } \\
\hline & & Latitude & Longitude & $\begin{array}{l}\text { Elevation } \\
\text { (m a.s.1.) }\end{array}$ & $\begin{array}{l}\text { Mean annual } \\
\text { temperature }\left({ }^{\circ} \mathrm{C}\right)\end{array}$ & $\begin{array}{l}\text { Annual } \\
\text { precipitation (mm) }\end{array}$ & Soil type \\
\hline Bosnia and Herzegovina & BA 04 & $43^{\circ} 44^{\prime} 55^{\prime \prime} \mathrm{N}$ & $18^{\circ} 15^{\prime} 3^{\prime \prime} \mathrm{E}$ & 1291 & 6.4 & 1371 & Rendzina \\
\hline Bulgaria & BG 01 & $41^{\circ} 55^{\prime} 6^{\prime \prime} \mathrm{N}$ & $23^{\circ} 50^{\prime} 29^{\prime \prime} \mathrm{E}$ & 1569 & 2.9 & 1118 & Cambisol \\
\hline Bulgaria & BG 02 & $41^{\circ} 57^{\prime} 55^{\prime \prime} \mathrm{N}$ & $24^{\circ} 31^{\prime} 14^{\prime \prime} \mathrm{E}$ & 1391 & 3.6 & 1007 & Luvisol \\
\hline Germany & DE 03 & $47^{\circ} 35^{\prime} 38^{\prime \prime} \mathrm{N}$ & $11^{\circ} 41^{\prime} 41^{\prime \prime} \mathrm{E}$ & 1271 & 4.8 & 2173 & Rendzina \\
\hline Germany & DE 09 & $47^{\circ} 44^{\prime} 10^{\prime \prime} \mathrm{N}$ & $12^{\circ} 21^{\prime} 51^{\prime \prime} \mathrm{E}$ & 902 & 5.1 & 2216 & Rendzina \\
\hline Germany & DE 12 & $47^{\circ} 42^{\prime} 50^{\prime \prime} \mathrm{N}$ & $12^{\circ} 42^{\prime} 27^{\prime \prime} \mathrm{E}$ & 973 & 5.8 & 1757 & Rendzina \\
\hline Germany & DE 14 & $47^{\circ} 26^{\prime} 52^{\prime \prime} \mathrm{N}$ & $11^{\circ} 7^{\prime} 24^{\prime \prime} \mathrm{E}$ & 1235 & 4.8 & 1454 & Rendzina \\
\hline Germany & DE 18 & $47^{\circ} 42^{\prime} 56^{\prime \prime} \mathrm{N}$ & $12^{\circ} 40^{\prime} 9^{\prime \prime} \mathrm{E}$ & 884 & 6.6 & 1653 & Rendzina \\
\hline Germany & DE 19 & $47^{\circ} 36^{\prime} 3^{\prime \prime} \mathrm{N}$ & $11^{\circ} 39^{\prime} 43^{\prime \prime} \mathrm{E}$ & 1091 & 6.1 & 1900 & Rendzina \\
\hline Germany & DE 27 & $48^{\circ} 51^{\prime} 19^{\prime \prime} \mathrm{N}$ & $13^{\circ} 35^{\prime} 18^{\prime \prime} \mathrm{E}$ & 743 & 6.6 & 1064 & Cambisol \\
\hline Slovakia & SK 01 & $48^{\circ} 38^{\prime} 34^{\prime \prime} \mathrm{N}$ & $19^{\circ} 32^{\prime} 21^{\prime \prime} \mathrm{E}$ & 850 & 5.6 & 861 & Cambisol \\
\hline Slovakia & SK 02 & $48^{\circ} 46^{\prime} 22^{\prime \prime} \mathrm{N}$ & $20^{\circ} 44^{\prime} 36^{\prime \prime} \mathrm{E}$ & 773 & 5.6 & 896 & Cambisol \\
\hline Slovakia & SK 03 & $48^{\circ} 46^{\prime} 18^{\prime \prime} \mathrm{N}$ & $20^{\circ} 43^{\prime} 32^{\prime \prime} \mathrm{E}$ & 738 & 5.8 & 874 & Cambisol \\
\hline Slovakia & SK 04 & $48^{\circ} 47^{\prime} 23^{\prime \prime} \mathrm{N}$ & $20^{\circ} 40^{\prime} 7^{\prime \prime} \mathrm{E}$ & 621 & 6.2 & 802 & Cambisol \\
\hline Slovakia & SK 05 & $48^{\circ} 45^{\prime} 35^{\prime \prime} \mathrm{N}$ & $20^{\circ} 42^{\prime} 56^{\prime \prime} \mathrm{E}$ & 845 & 5.4 & 941 & Cambisol \\
\hline Slovakia & SK 07 & $48^{\circ} 37^{\prime} 26^{\prime \prime} \mathrm{N}$ & $19^{\circ} 35^{\prime} 59^{\prime \prime} \mathrm{E}$ & 786 & 6.0 & 888 & Cambisol \\
\hline Slovakia & SK 08 & $48^{\circ} 37^{\prime} 55^{\prime \prime} \mathrm{N}$ & $19^{\circ} 34^{\prime} 17^{\prime \prime} \mathrm{E}$ & 733 & 6.2 & 855 & Cambisol \\
\hline Slovenia & SI 01 & $45^{\circ} 39^{\prime} 51^{\prime \prime} \mathrm{N}$ & $15^{\circ} 0^{\prime} 25^{\prime \prime} \mathrm{E}$ & 910 & 6.7 & 1812 & Rendzina \\
\hline Slovenia & SI 02 & $46^{\circ} 14^{\prime} 49^{\prime \prime} \mathrm{N}$ & $14^{\circ} 3^{\prime} 40^{\prime \prime} \mathrm{E}$ & 1375 & 4.5 & 2767 & Rendzina \\
\hline Switzerland & CH 01 & $46^{\circ} 57^{\prime} 34^{\prime \prime} \mathrm{N}$ & $7^{\circ} 46^{\prime} 25^{\prime \prime} \mathrm{E}$ & 890 & 6.9 & 1426 & Cambisol \\
\hline
\end{tabular}

Note: Soil type is based on the nomenclature of the Food and Agriculture Organization (FAO) of the United Nations (IUSS Working Group WRB 2015). Climate data display the mean of the period 1901-2018 (Climatic Research Unit (CRU) database; Harris et al. 2014). Information on soil properties is based on the European Soil Database version 2.0 (Panagos et al. 2012).

Johann; Digitalpositiometer, Britz and Hatzl GmbH, Austria). We measured the annual ring widths on each core and cross-dated the individual tree-ring width time series. The radial increments, ir, of the two cores of a tree $\left(\mathrm{ir}_{1}\right.$ and $\mathrm{ir}_{2}$ ) were added to obtain a representative time series of diameter increment, id, for each tree (id = $\mathrm{ir}_{1}+\mathrm{ir}_{2}$ ).

For those trees with cores that did not reach the pith, the age was estimated from the sum of the number of growth rings of the core ( $\mathrm{NGR}_{\text {core }}$ ) and an estimate of the missing number of growth rings $\left(\mathrm{NGR}_{\text {missing }}\right)$ by applying the equation Age $=\mathrm{NGR}_{\text {core }}+$

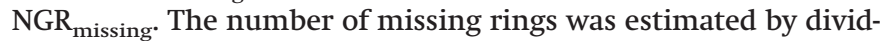
ing the last known diameter by the mean diameter increment of the first 30 years. Table 2 and Supplementary Table $S 1^{1}$ provide an overview of the tree-ring data used for this study.

\subsection{Statistical evaluation}

\subsubsection{Linearity of diameter growth over age}

To test past tree diameter growth over age for linearity versus nonlinearity, we used the following simple model:

$$
\mathrm{D}=k \times \mathrm{AGE}^{a_{1}}
$$

which is equivalent to

$$
\ln (D)=a_{0}+a_{1} \times \ln (\mathrm{AGE}) \quad \text { with } a_{0}=\ln (k)
$$

where $D$ is tree DBH (in millimetres), AGE is tree age (in years), $k$ is a scaling parameter, and $a_{1}$ is the exponent - which is most crucial for our research question. When $a_{1}=1$, eq. 1 describes linear growth. When $a_{0}<1$ or $a_{1}>1$, the equation describes nonlinear growth, with decreasing or increasing growth rates, respectively. We chose this simple model because more complex (e.g., sigmoid) patterns could be ruled out after visual data inspection. This concept was applied to the full data set, but separately for each tree species, by way of a mixed linear regression model as follows:

$$
\begin{aligned}
\ln \left(D_{i j k}\right)=a_{0}+a_{1} \times \ln \left(\mathrm{AGE}_{i j k}\right) & +b_{i}+b_{i j} \\
& +\left(c_{i}+c_{i j}\right) \times \ln \left(\mathrm{AGE}_{i j k}\right)+\varepsilon_{i j k}
\end{aligned}
$$

The fixed-effect parameters $a_{0}$ and $a_{1}$ have exactly the same meaning as in eq. $1 b$; if $a_{1}$ is not significantly different from 1 , we would assume a linear growth process. The indexes $i, j$, and $k$ in eq. 2 refer to the levels of plot, tree on plot, and single observation, respectively. To account for autocorrelation, random effects $b$ and $c$ were applied on the levels of plot and tree on plot. Whereas the random effect $b$ relates to the intercept $a_{0}$, the random effect $c$ refers to the slope $a_{1}$. All random effects were assumed to be normally distributed with an expected mean of 0 . The decision to accept the full random-effect model as shown in eq. 2 or potentially simpler subforms was made based on the Akaike information criterion (AIC) (Burnham and Anderson 2004). The uncorrelated remaining errors are $\varepsilon_{i j k}$.

${ }^{1}$ Supplementary data are available with the article through the journal Web site at http://nrcresearchpress.com/doi/suppl/10.1139/cjfr-2019-0368. 
Table 2. Overview of the tree-ring data used for this study.

\begin{tabular}{|c|c|c|c|c|c|c|c|c|c|c|c|c|c|c|c|}
\hline \multirow[b]{2}{*}{ Species } & \multirow[b]{2}{*}{ Country } & \multirow[b]{2}{*}{$\begin{array}{l}\text { No. of } \\
\text { plots }\end{array}$} & \multirow[b]{2}{*}{$\begin{array}{l}\text { No. of } \\
\text { trees }\end{array}$} & \multicolumn{3}{|c|}{$\mathrm{DBH}(\mathrm{cm})$} & \multicolumn{3}{|c|}{ DBH-year } & \multicolumn{3}{|c|}{ No. of growth rings } & \multicolumn{3}{|c|}{$\begin{array}{l}\text { Diameter increment } \\
\left(\mathrm{mm} \cdot \text { year }^{-1}\right)\end{array}$} \\
\hline & & & & Min & Median & $\operatorname{Max}$ & Min & Median & $\operatorname{Max}$ & Min & Median & $\operatorname{Max}$ & Min & Median & $\operatorname{Max}$ \\
\hline European beech & Bulgaria & 2 & 47 & 23.0 & 35.6 & 56.6 & 1867 & 1903 & 1926 & 79 & 104 & 124 & 0.18 & 2.82 & 13.87 \\
\hline European beech & Germany & 9 & 173 & 25.2 & 46.8 & 95.2 & 1446 & 1826 & 1933 & 59 & 141 & 331 & 0.12 & 2.04 & 15.10 \\
\hline European beech & Slovenia & 4 & 47 & 31.1 & 43.0 & 79.7 & 1571 & 1853 & 1902 & 101 & 142 & 377 & 0.12 & 2.14 & 13.64 \\
\hline European beech & Switzerland & 1 & 9 & 40.9 & 49.9 & 68.8 & 1858 & 1909 & 1943 & 72 & 107 & 155 & 0.36 & 3.68 & 16.78 \\
\hline Silver fir & $\begin{array}{l}\text { Bosnia and } \\
\text { Herzegovina }\end{array}$ & 2 & 46 & 42.3 & 151.5 & 198.0 & 1040 & 1733 & 1928 & 40 & 93 & 183 & 0.08 & 3.79 & 14.36 \\
\hline Silver fir & Bulgaria & 2 & 52 & 27.2 & 45.6 & 69.6 & 1883 & 1917 & 1963 & 42 & 87 & 119 & 0.36 & 3.99 & 15.18 \\
\hline Silver fir & Germany & 9 & 170 & 34.2 & 58.5 & 124.5 & 1455 & 1817 & 1906 & 70 & 154 & 415 & 0.06 & 2.51 & 19.41 \\
\hline Norway spruce & Bulgaria & 1 & 28 & 41.9 & 58.0 & 71.4 & 1888 & 1911 & 1938 & 64 & 91 & 116 & 0.74 & 4.34 & 16.75 \\
\hline Norway spruce & Germany & 9 & 207 & 26.5 & 55.9 & 102.2 & 1273 & 1839 & 1939 & 52 & 138 & 357 & 0.04 & 2.55 & 16.30 \\
\hline Norway spruce & Serbia & 1 & 29 & 32.9 & 39.8 & 49.7 & 1884 & 1900 & 1910 & 91 & 108 & 113 & 0.47 & 3.20 & 10.16 \\
\hline Norway spruce & Slovakia & 1 & 30 & 45.3 & 56.5 & 69.4 & 1864 & 1897 & 1906 & 89 & 106 & 117 & 0.59 & 3.66 & 15.50 \\
\hline Norway spruce & Slovenia & 2 & 32 & 42.6 & 53.4 & 92.4 & 1791 & 1877 & 1929 & 77 & 127 & 217 & 0.12 & 3.51 & 19.69 \\
\hline Norway spruce & Switzerland & 1 & 14 & 38.4 & 55.6 & 76.9 & 1806 & 1901 & 1960 & 49 & 92 & 143 & 0.06 & 4.02 & 28.40 \\
\hline
\end{tabular}

Note: This table presents the whole data set, which was used for fitting the models according to eqs. 2 and 3. Values of DBH (diameter at breast height) and age are from the year 2017, except for the values from six plots in Slovakia (SK 02 to SK 08), which were inventoried in 2011. Note that for fitting the model according to eq. 4, we eliminated all trees with DBH-year (calendar year when a tree reached a height of $1.3 \mathrm{~m}$ ) earlier than 1600 (see Supplementary Table S11). Min, minimum; Max, maximum.

\subsubsection{Temporal trends in diameter growth}

The analyses with eq. 2 indicated linear diameter growth over age; therefore, we used the following mixed linear model for investigating temporal trends concerning the level and the steepness of the diameter-age relationship:

$$
\begin{aligned}
\ln \left(D_{i j k}\right)=a_{0}+ & a_{1} \times \ln \left(\mathrm{AGE}_{i j k}\right)+a_{2} \times \operatorname{DYEAR}_{i j} \\
& +a_{3} \times \ln \left(\mathrm{AGE}_{i j k}\right) \times \mathrm{DYEAR}_{i j}+b_{i}+b_{i j}+\varepsilon_{i j k}
\end{aligned}
$$

Except for the fixed effects and their parameters $\left(a_{0}, a_{1}, a_{2}\right.$, and $a_{3}$ ), the notation of this model is exactly the same as for eq. 2 . The fixed effect DYEAR (abbreviation for "DBH-year") indicates the calendar year when a given tree had a DBH for the first time (i.e., when the height of $1.3 \mathrm{~m}$ was reached). A significant estimate of $a_{2}$ would indicate that there was a temporal trend of the diameterage relationship's level, whereas a significant value of $a_{3}$ would indicate a temporal trend in the slope. As with the model in eq. 2 , the AIC was applied for deciding between the full set of random effects and simpler subsets.

\subsubsection{Temporal growth trends and elevation}

For testing the combined influence of age, DBH-year, and elevation, we formulated a mixed linear regression model, which can be seen as an extended combination of eqs. 2 and 3 :

$$
\begin{array}{r}
\ln \left(D_{i j k}\right)=a_{0}+a_{1} \times \ln \left(\mathrm{AGE}_{i j k}\right)+a_{2} \times \mathrm{DYEAR}_{i j}+a_{3} \times \mathrm{ALT}_{i j}+a_{4} \times \operatorname{deMARTONNE}_{i j}+a_{5} \times \ln \left(\mathrm{AGE}_{i j k}\right) \times \mathrm{DYEAR}_{i j} \\
+a_{6} \times \ln \left(\mathrm{AGE}_{i j \mathrm{k}}\right) \times \mathrm{ALT}_{i j}+a_{7} \times \ln \left(\mathrm{AGE}_{i j \mathrm{k}}\right) \times \mathrm{deMARTONNE}_{i j}+a_{8} \times \mathrm{DYEAR}_{i j} \times \mathrm{ALT}_{i j}+a_{9} \times \mathrm{DYEAR}_{i j} \times \operatorname{deMARTONNE}_{i j} \\
+a_{10} \times \mathrm{ALT}_{i j} \times \operatorname{deMARTONNE}_{i j}+b_{i}+b_{i j}+\varepsilon_{i j k}
\end{array}
$$

Again, the meaning of the notation is the same as in eqs. 2 and 3; the only new variables were the fixed effect ALT and deMARTONNE, which stand for a given plot's elevation above sea level in metres and the de Martonne aridity index (de Martonne 1926), respectively.

$$
\text { deMARTONNE }=\text { annual precipitation } /
$$$$
\text { (annual mean temperature }+10 \text { ) }
$$

We added the de Martonne aridity index (e.g., Bielak et al. 2014; Pretzsch et al. 2015) in our model, as elevation is not sufficient for characterizing the site-specific water supply along elevational gradients (Körner 2003; Lauscher 1976; Khurshid-Alam 1972).

The fixed effects in this model cover the main effects $\ln (\mathrm{AGE})$, DYEAR, ALT, and deMARTONNE and all of their two-way interactions. When fitting the model, nonsignificant interactions were removed and the model was refitted, but if an interaction was significant, the contributing main effects were kept in the model even when not significant, following a protocol suggested by Zuur et al. (2009). The decision about the random effects to be kept in the model was made in the same way as described for eqs. 2 and 3. The model was fitted for each species separately. To avoid conver- 
Fig. 2. Trajectories of stem diameter at breast height (DBH) and tree age for the 382 Norway spruce, 679 silver fir, and 660 European beech trees during the last few centuries, in double logarithmic representation. Most trees show a linear increase in stem diameter with progressing age (reference lines $\ln (D)=a_{0}+a_{1} \times \ln$ (AGE) with $a_{0}=1$ and varying $a_{0}$ ) and no asymptotic growth curve pattern. [Colour online.]
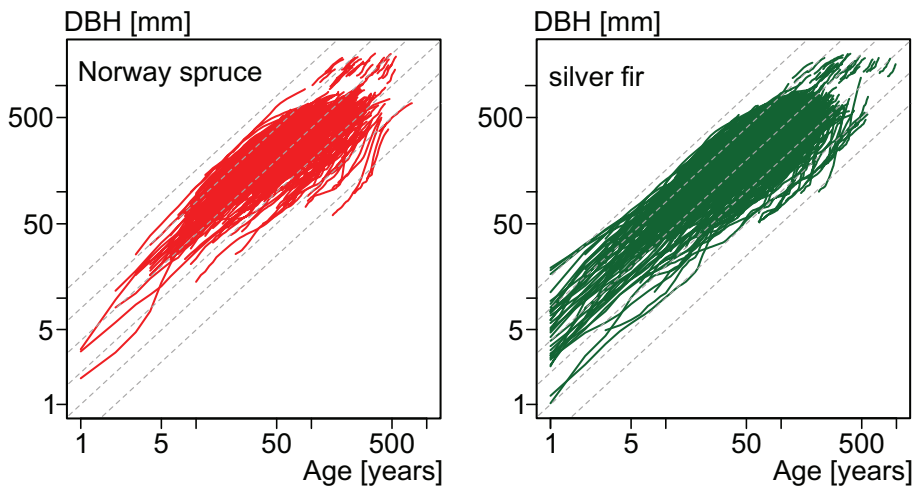

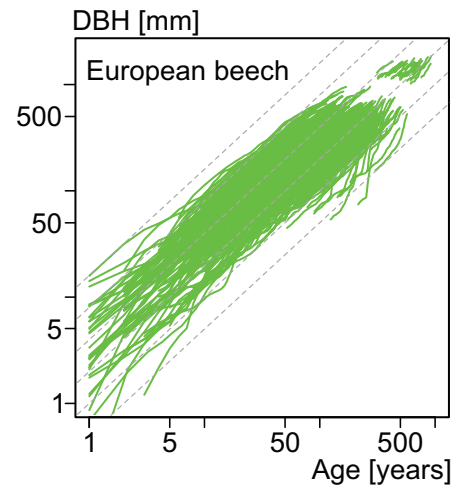

Table 3. Results of fitting the linear mixed-effect model from eq. 2 to the Norway spruce data.

\begin{tabular}{llllc}
\hline Fixed-effect variable & $\begin{array}{l}\text { Fixed-effect } \\
\text { parameter }\end{array}$ & Estimate & SE & $p$ \\
\hline & $a_{0}$ & $\mathbf{1 . 4 6 0 9}$ & 0.4925 & $\mathbf{0 . 0 0 3}$ \\
$\ln (\mathrm{AGE})$ & $a_{1}$ & $\mathbf{0 . 9 8 0 4}$ & 0.0945 & $\mathbf{< 0 . 0 0 0 1}$ \\
\hline & Random & & & \\
& effect & SD & & \\
\hline & $b_{i}$ & 1.2622 & & \\
& $b_{i j}$ & 1.7871 & & \\
$c_{i}$ & 0.2445 & & \\
\hline$c_{i j}$ & 0.2891 & & \\
\hline & Residual & SD & & \\
\hline & $\varepsilon_{i j k}$ & 0.0697 & & \\
\hline
\end{tabular}

Note: Comparisons of the Akaike information criterion (AIC) suggested using the full set of random effects. See section 2.2 for definitions of variables. SE, standard error; SD, standard deviation.

gence issues with this model, DBH-years earlier than 1600 were omitted from the data. Mixed-effect models were computed using the R package nlme (Pinheiro et al. 2018; R Core Team 2018).

\section{Results}

\subsection{Linearity of diameter growth over age}

Figure 2 provides an overview of all trees' diameter-age trajectories in a double logarithmic coordinate system. Visually compared with the reference lines, which represent an exponent $a_{1}=1$ (cf. eqs. $1 a$ and $1 b$ ), the trajectories suggest a generally linear growth pattern. The growth trajectories in the upper right corner of the graphs were derived from very old stands. They cover several hundred years but appear short in the graphs because of the logarithmic scale.

As shown in Tables 3-5, the estimates of the fixed effect $a_{1}$ for spruce, fir, and beech were 0.9804 (standard error (SE) 0.0945), 1.0597 (SE 0.0843), and 1.0559 (SE 0.0731), respectively. For all three species, 1 was within $a_{1} \pm 1.96 \times$ SE. This indicates no significant deviation from linear diameter growth over age for each of the three tree species as illustrated in Fig. 3. As there were linear relationships, the slope of the diameter-age lines shown in the right panel of Fig. 3 results from $\mathrm{e}^{a_{0}}$. We thus obtained mean diameter growth rates of 4.31, 2.81, and $1.96 \mathrm{~mm} \cdot \mathrm{year}^{-1}$ for spruce, fir, and beech, respectively.

\subsection{Temporal trends in diameter growth}

The results obtained by fitting the regression model from eq. 3 are listed in Tables 6-8. All fixed-effect parameters were significant with $p<0.0001$, indicating clear temporal trends, with all
Table 4. Results of fitting the linear mixed-effect model from eq. 2 to the silver fir data.

\begin{tabular}{llllr}
\hline Fixed-effect variable & $\begin{array}{l}\text { Fixed-effect } \\
\text { parameter }\end{array}$ & Estimate & SE & \multicolumn{1}{c}{$p$} \\
\hline & $a_{0}$ & $\mathbf{1 . 0 3 4 5}$ & 0.3966 & $\mathbf{0 . 0 0 9 1}$ \\
$\ln$ (AGE) & $a_{1}$ & $\mathbf{1 . 0 5 9 7}$ & 0.0843 & $<\mathbf{0 . 0 0 0 1}$ \\
\hline & Random & & & \\
& effect & SD & & \\
\hline & $b_{i}$ & 0.8842 & & \\
& $b_{i j}$ & 1.9129 & & \\
& $c_{i}$ & 0.1543 & & \\
& $c_{i j}$ & 0.3180 & & \\
\hline & Residual & SD & & \\
\hline & $\varepsilon_{i j k}$ & 0.0844 & & \\
\hline
\end{tabular}

Note: AIC comparisons suggested using the full set of random effects.

tree species exhibiting a similar pattern. For all species, we found positive main effects of age and DBH-year and a slight negative effect of the interaction between DBH-year and age. For all species, this leads, over the past 300 years, as Fig. 4 shows, to a pronounced increase of the diameter-age relationship and a slight increase of the slope.

Figure 5 compares the species-wise results directly. The aforementioned trends steepen the diameter-age relationship from 1700 to present. They were strongest for silver fir and European beech and least pronounced for Norway spruce. This means that, given increasing growth levels and slopes for all species, the age trends among the species were spruce $\gg$ fir $>$ beech in 1700 but have changed to rather similar trends (spruce $\cong$ fir $\cong$ beech), indicating more similar growth vigour in 1800 and 1900.

\subsection{Temporal growth trends and elevation}

For Norway spruce, the growth trend did not change with elevation (Fig. 6; Table 9). Although elevation as a main effect had no significant ( $p=0.9102)$ influence on the level of the diameter-age relationship, there was a significant positive interaction of elevation with $\ln ($ AGE). However, this was counteracted by a significant negative interaction of elevation with deMARTONNE. We could not identify any elevation-dependent changes in growth during the last 300 years for Norway spruce. The de Martonne aridity index had a significant negative effect on the diameter-age relationship. This was counteracted by a significant positive effect of the interaction of deMARTONNE with $\ln$ (AGE) and DYEAR. Whereas in the past (DBH-year 1700) Norway spruce trees showed higher growth with lower de Martonne indices, this trend was reverted to higher growth with higher de Martonne indices for trees with a DBH-year of 1900 . Our results suggested large differ- 
Table 5. Results of fitting the linear mixed-effect model from eq. 2 to the European beech data.

\begin{tabular}{|c|c|c|c|c|}
\hline Fixed-effect variable & $\begin{array}{l}\text { Fixed-effect } \\
\text { parameter }\end{array}$ & Estimate & SE & $p$ \\
\hline \multirow{9}{*}{$\ln (\mathrm{AGE})$} & $a_{0}$ & 0.6720 & 0.3374 & 0.0464 \\
\hline & $a_{1}$ & 1.0559 & 0.0731 & $<0.0001$ \\
\hline & $\begin{array}{l}\text { Random } \\
\text { effect }\end{array}$ & SD & & \\
\hline & $b_{i}$ & 0.6899 & & \\
\hline & $b_{i j}$ & 1.7215 & & \\
\hline & $c_{i}$ & 0.1078 & & \\
\hline & $c_{i j}$ & 0.2962 & & \\
\hline & Residual & SD & & \\
\hline & $\varepsilon_{i j k}$ & 0.0823 & & \\
\hline
\end{tabular}

ences in growth with fluctuating de Martonne indices at the same elevation (Supplementary Fig. S11).

Silver fir showed elevation-related trends (Fig. 7; Table 10). Although elevation significantly $(p<0.0001)$ reduced the level of the diameter-age relationship, this was counteracted by a significant positive interaction of elevation with DYEAR and $\ln (\mathrm{AGE})$. This means that there was an elevation-related differentiation of the general growth trend towards increasing growth with increasing DBH-year. Our model suggested that in the past (DBH-year 1700), growth of silver fir was highest at low elevations and lowest at high elevations. This behaviour of silver fir changed from 1700 to present. Regarding the de Martonne aridity index, our results showed a significant negative effect on the diameter-age relationship. This was counteracted by a significant negative interaction of deMARTONNE with DYEAR and $\ln (\mathrm{AGE})$. Whereas in the past the growth of silver fir became higher as the de Martonne index increased, this trend was nonexistent or even reverted for trees with a DBH-year of 1900 (Supplementary Fig. S2 ${ }^{1}$ ).

Similar results were found for European beech (Fig. 8; Table 11). We detected a contrasting trend for elevation and its interactions with other variables. Whereas the significant effect of elevation $(p<0.0001)$ suggested a general trend towards lower growth with higher elevations, this was counteracted by positive interactions of elevation with $\ln (\mathrm{AGE})$ and DYEAR. As Fig. 8 shows, the model suggested higher growth with decreasing elevation for trees with a DBH-year of 1700. This elevation-related ranking, however, changed strongly with time. For trees with a DBH-year of 1900, the initial trend totally reverted; trees at higher elevations showed clearly higher growth rates. The elevation effects took place inside the general pattern of increasing growth with increasing $\mathrm{DBH}$ year. The de Martonne aridity index had a significant $(p<0.0001)$ increasing influence on the level of the diameter-age relationship. This was counteracted by a significant negative interaction of deMARTONNE with $\ln (\mathrm{AGE})$. The interaction of deMARTONNE with DYEAR showed no significant effect. We could not find any changes of the growth of European beech in the last 300 years that were dependent on the de Martonne index (Supplementary Fig. $\left.S 3^{1}\right)$.

\section{Discussion}

\subsection{Integrated view on the revealed growth patterns}

The tree-ring analyses revealed that the relative competitiveness and fitness among the three species are changing - the balance of the past due to the interactions described in section 1 might be compromised. According to theory (von Bertalanffy 1951; Zeide 1993) and empirical findings (Assmann 1961; Kramer 1988; Weiner and Thomas 2001), the diameter-age curves of trees should show an asymptotic development of their course at advanced tree ages of 100-300 years. Although most of our sampled trees were at least 300 years old (see Supplementary Table S1), their diameter-age trajectories are still increasing linearly (Figs. 2 and 3). This phenomenon applies on average for all three species and suggests a large-scale change of the environmental conditions in the last decades. Obviously, the environmental conditions changed in a way that was, on average, beneficial for the growth of all three species and delayed the normal age-related ontogenetic drift and downturn of tree growth (Evans 1972). This general trend was an overarching pattern, but the three species differed in the strength of this trend and its occurrence at different elevations.

During the last 300 years, the mean growth rates, as well as the age trend of the three species, increased significantly (Fig. 4). Trees with an age of 75 years in 1700 grew much more slowly and followed a flatter age trend than trees with an age of 75 years in 1800 or 1900 . Whereas this overall pattern was similar for all species, they differed in the extent of this temporal shift of their diameter-age curves. The shift was lowest for Norway spruce and strongest for European beech (Fig. 5). This species-specific shift results in a remarkable change of the relative growth velocity of the three species. Three centuries ago, Norway spruce was clearly ahead of silver fir and European beech. This relationship has changed continuously and now favours silver fir and especially European beech. The trees with a DBH-year of 1900 follow rather similar diameter-age trajectories independent of the tree species. This change in the relative growth strength among the tree species is not the result of an absolute decrease of the growth and productivity of Norway spruce but a result of a lower increase of the growth and productivity compared with the other two, more successful species.

The analysis of growth trends at different elevations reveals an interesting elevation-specific change of growth behaviour for silver fir and European beech (Fig. 8). In stands with a DBH year of 1700 , the growth rates were initially higher at lower elevations, but this trend later reversed in direction. In DBH-year 1800 or 1900 , the growth was generally higher, but even the ranking of the growth at different elevations changed towards a superiority of the growth of silver fir and European beech at high elevations. This may suggest that the growing conditions for both species generally improved, but at higher elevations even more than at lower elevations (Fig. 8, middle and upper curves).

We sampled only dominant trees. In their very early juvenile phase, they might have been in sit-and-wait positions in the understorey of the stands. But based on the increment cores, we included only individuals without suppression phases during the last centuries. Thus, the sample trees represent the survivors of the population in the long term that had no long-term strong shading and only normal lateral interspecific competition by neighbouring trees. This means that their growth provides a good indication of responses to environmental conditions and relative growth levels and trends of the three species in the overstorey of mixed mountain forests. As the dominant trees represent the majority of the stand growth in mixed mountain forests (Magin 1959; Preuhsler 1979), the sampled trees may also indicate the growth trend and relative contribution of the species to the growth at the stand level.

\subsection{Significant growth changes of Norway spruce, silver fir, and European beech during the last three centuries}

Several studies suggest that the effects of climate warming are strongest at northern latitudes and higher elevations where the temperature and length of the growing season have been limiting growth. This applies especially for moist forest ecosystems where water limitation plays a minor role. Most studies on growth trends at high elevations have so far been based either on scenario analyses with simulation models (Nogués-Bravo et al. 2007; Theurillat and Guisan 2001) or on heating experiments (Saxe et al. 2001; Schindlbacher et al. 2011). Evidence based on long-term surveys combined with tree-ring analyses reaching back several hundred 
Fig. 3. Mean growth trend for Norway spruce, silver fir, and European beech during the last few centuries in double logarithmic and linear representation based on the statistical model from eq. 2 . On average, there was no declining increment trend with age, which would mean a turn towards an asymptotic diameter. The trend is linear for all three species, with the following ranking regarding the steepness of the slope: silver fir > European beech $>$ Norway spruce.

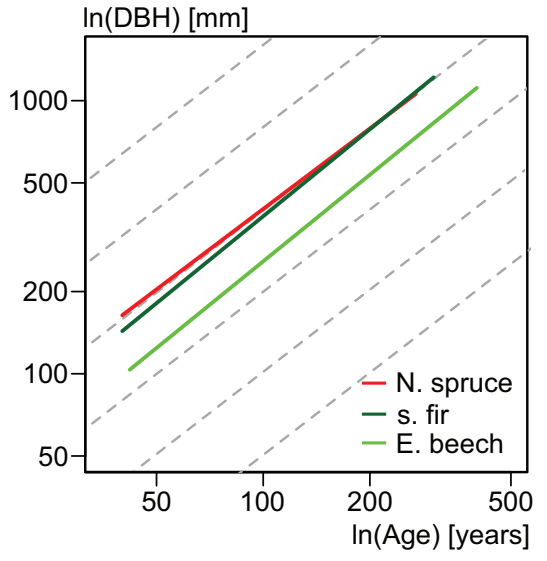

Table 6. Results of fitting the linear mixed-effect model from eq. 3 to the Norway spruce data.

\begin{tabular}{llrll}
\hline \multirow{2}{*}{ Fixed-effect variable } & $\begin{array}{l}\text { Fixed-effect } \\
\text { parameter }\end{array}$ & Estimate & \multicolumn{1}{l}{ SE } & \multicolumn{1}{l}{$p$} \\
\hline & $a_{0}$ & $\mathbf{- 1 7 . 1 7 4 3}$ & 0.4001 & $<\mathbf{0 . 0 0 0 1}$ \\
$\ln ($ AGE) & $a_{1}$ & $\mathbf{3 . 0 6 6 9}$ & 0.0369 & $<\mathbf{0 . 0 0 0 1}$ \\
DYEAR & $a_{2}$ & $\mathbf{0 . 0 1 0 2}$ & 0.0002 & $<\mathbf{0 . 0 0 0 1}$ \\
$\ln ($ AGE) $\times$ DYEAR & $a_{3}$ & $\mathbf{- 0 . 0 0 1 1}$ & 0.0001 & $<\mathbf{0 . 0 0 0 1}$ \\
\hline & Random & & & \\
& effect & SD & & \\
\hline & $b_{i}$ & 0.2598 & & \\
& $b_{i j}$ & 0.2592 & & \\
\hline & Residual & SD & & \\
\hline & $\varepsilon_{i j k}$ & 0.1244 & & \\
\hline
\end{tabular}

Note: AIC comparisons suggested using the full set of random effects.

Table 7. Results of fitting the linear mixed-effect model from eq. 3 to the silver fir data.

\begin{tabular}{llrll}
\hline & Fixed-effect & & & \\
Fixed-effect variable & parameter & Estimate & SE & \multicolumn{1}{l}{$p$} \\
\hline & $a_{0}$ & $\mathbf{- 1 3 . 4 6 3 4}$ & 0.5315 & $<\mathbf{0 . 0 0 0 1}$ \\
$\ln ($ AGE) & $a_{1}$ & $\mathbf{2 . 1 5 6 5}$ & 0.0375 & $<\mathbf{0 . 0 0 0 1}$ \\
DYEAR & $a_{2}$ & $\mathbf{0 . 0 0 8 3}$ & 0.0003 & $<\mathbf{0 . 0 0 0 1}$ \\
$\ln ($ AGE) $\times$ DYEAR & $a_{3}$ & $\mathbf{- 0 . 0 0 0 7}$ & 0.0001 & $<\mathbf{0 . 0 0 0 1}$ \\
\hline & Random & & & \\
& effect & SD & & \\
\hline & $b_{i}$ & 0.1504 & & \\
& $b_{i j}$ & 0.3102 & & \\
\hline & Residual & SD & & \\
\hline & $\varepsilon_{i j k}$ & 0.1641 & & \\
\hline
\end{tabular}

Note: AIC comparisons suggested using the full set of random effects.

years and covering a representative region of European mixed mountain forests has been missing (Kräuchi et al. 2000).

In the study area, all three species, on average, show an increasing growth trend. This corresponds with growth trends revealed for lowland forests in many parts of Central Europe (Kauppi et al. 2014; Pretzsch et al. 2014; Spiecker 2000). Compared with the findings in the lowland and boreal areas, the acceleration in the mixed mountain forests is even stronger. The diameter growth curves showed no asymptotic turn towards a final diameter, even

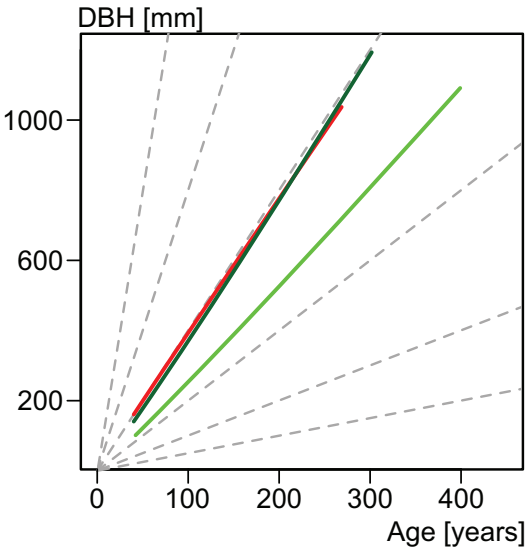

Table 8. Results of fitting the linear mixed-effect model from eq. 3 to the European beech data.

\begin{tabular}{lllll}
\hline & Fixed-effect & & & \\
Fixed-effect variable & parameter & Estimate & SE & \multicolumn{1}{l}{$p$} \\
\hline & $a_{0}$ & $\mathbf{- 7 . 1 7 7 8}$ & 0.4001 & $<\mathbf{0 . 0 0 0 1}$ \\
AGE & $a_{1}$ & $\mathbf{1 . 1 9 8 2}$ & 0.0369 & $<\mathbf{0 . 0 0 0 1}$ \\
DYEAR & $a_{2}$ & $\mathbf{0 . 0 0 4 7}$ & 0.0002 & $<\mathbf{0 . 0 0 0 1}$ \\
AGE $\times$ DYEAR & $a_{3}$ & $\mathbf{- 0 . 0 0 0 2}$ & 0.0001 & $<\mathbf{0 . 0 0 0 1}$ \\
\hline & Random & & & \\
& effect & SD & & \\
\hline & $b_{i}$ & 0.0004 & & \\
& $b_{i j}$ & 0.3005 & & \\
\hline & Residual & SD & & \\
\hline & $\varepsilon_{i j k}$ & 0.1711 & & \\
\hline
\end{tabular}

Note: AIC comparisons suggested using the full set of random effects.

for very old trees. Although we included only trees that did not show distinct suppression phases in their ring patterns in the past (see section 2), the persistent growth may partly be a sampling effect. At present, the sample trees are dominant, but some might have been subdominant and slow growing in the past and, as a consequence, persistently growing even until high ages as shown by von Guttenberg (1915). In addition, the growth of the tree in advanced ages may be accelerated by changed environmental conditions.

We hypothesize that the increased temperature and extended growing season, the fertilizing effect of nitrogen deposition, and the elevated $\mathrm{CO}_{2}$ concentration may contribute to this general pattern. Rising temperature alone, as a main factor, is rather unlikely (Fig. 9). An increase in temperature by $2{ }^{\circ} \mathrm{C}$ as assumed in the niche diagram (grey hatched stripes from positions 1, 2, and 3 in Fig. 9) would leave the growth of Norway spruce at higher elevations (position 1) rather unmodified but would strongly reduce it at middle (position 2) and lower (position 3) elevations of our study area. This differs considerably from the general positive pattern that we found. For European beech and silver fir, a temperature increase of $2{ }^{\circ} \mathrm{C}$ would strongly increase growth at the higher and middle elevations but would cause no changes at the lower elevations. Again, this does not correspond with the expected pattern, as we found an increase at all elevations. Consequently, temperature changes may be only one of several important factors. 
Fig. 4. Changes of the level and the slope of the diameter growth curves for the three species during the last three centuries according to the results obtained by fitting the mixed linear model from eq. 3. DBH-years 1700, 1800, and 1900 (abbreviated as DYEAR in eq. 3) mean that the trees reached a height of $1.3 \mathrm{~m}$ in the years 1700, 1800, and 1900 and are 320, 220, and 120 years old at present (in 2020), respectively. [Colour online.]
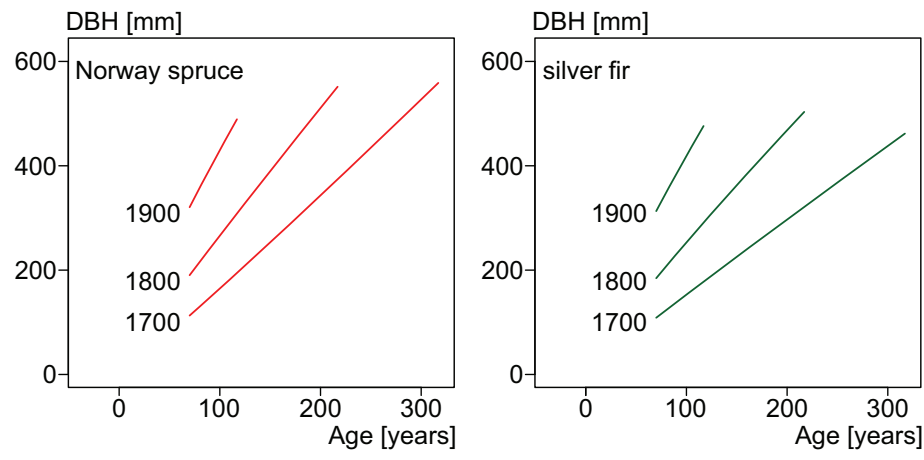

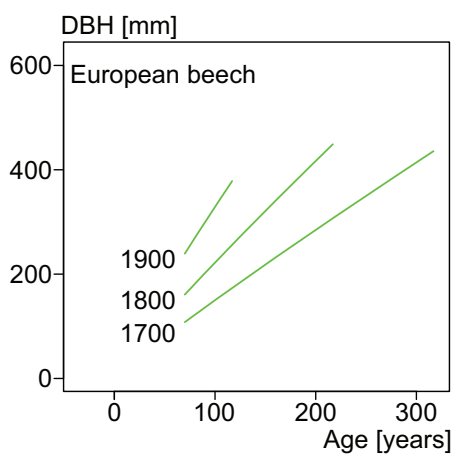

Fig. 5. Overview of the changes in the level and steepness of the growth curves of Norway spruce, silver fir, and European beech during the last three centuries (based on regression model of eq. 3).

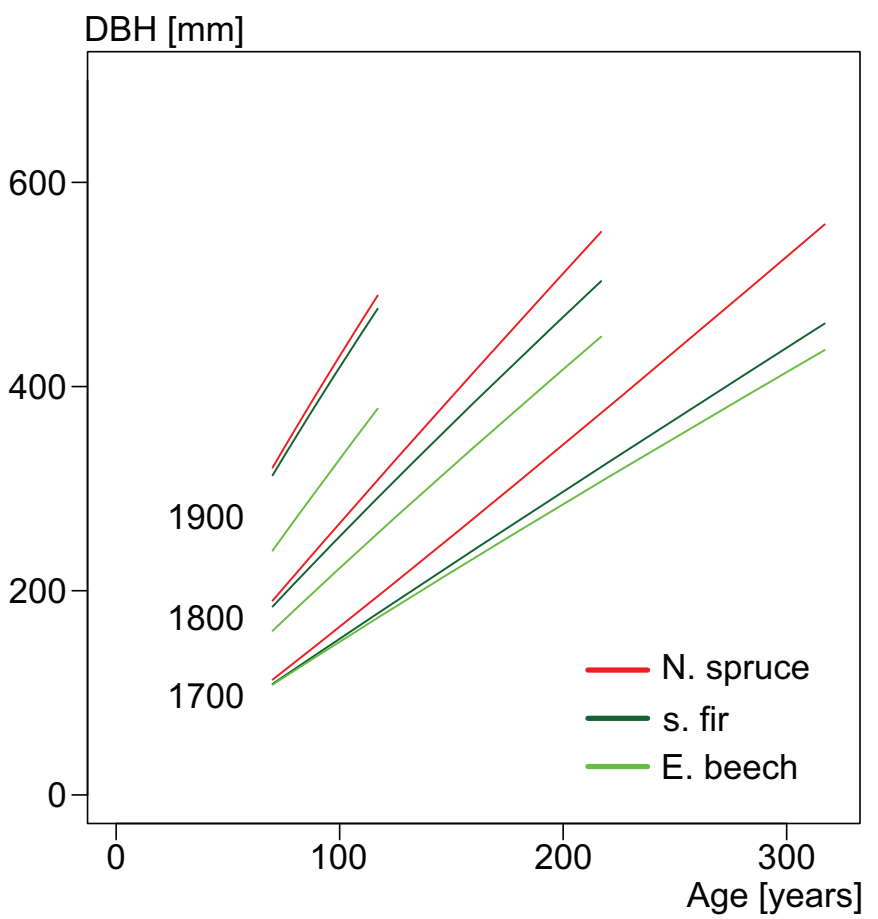

\subsection{Species-specific and elevation-dependent reaction pattern}

Our study provides a model example for a reversing, elevationdependent growth response of species. Silver fir and especially European beech thrive at higher elevations because of improved growing conditions and lower competition by Norway spruce. Simultaneously, their growth hardly changes at lower elevations. Of course, elevation is just used as a proxy for mean annual temperature and length of the growing season in this region (Körner 2007). Especially in mountain forests with temperature limitations and short growing seasons, the extended length of the growing season (Menzel and Fabian 1999) may cause a long-term acceleration of tree growth (White et al. 1999).

However, there are other climatic trends (e.g., precipitation), which are not generally related to elevation. Thus, we were able to show that not only the elevation, but also the de Martonne aridity index, has a significant effect on the growth of Norway spruce. At the same elevation, Norway spruce showed clear differences in
Fig. 6. Elevation-dependent changes of the growth of Norway spruce in the last 300 years (based on the regression model after eq. 4). For the predictions, the de Martonne aridity index was kept constant (mean value). Note that the rigid log-linearity caused large DBH differences in the young ages. The trends, however, were not influenced by this. See Supplementary Fig. S1 for changes depending on the de Martonne aridity index. ${ }^{1}$ [Colour online.]

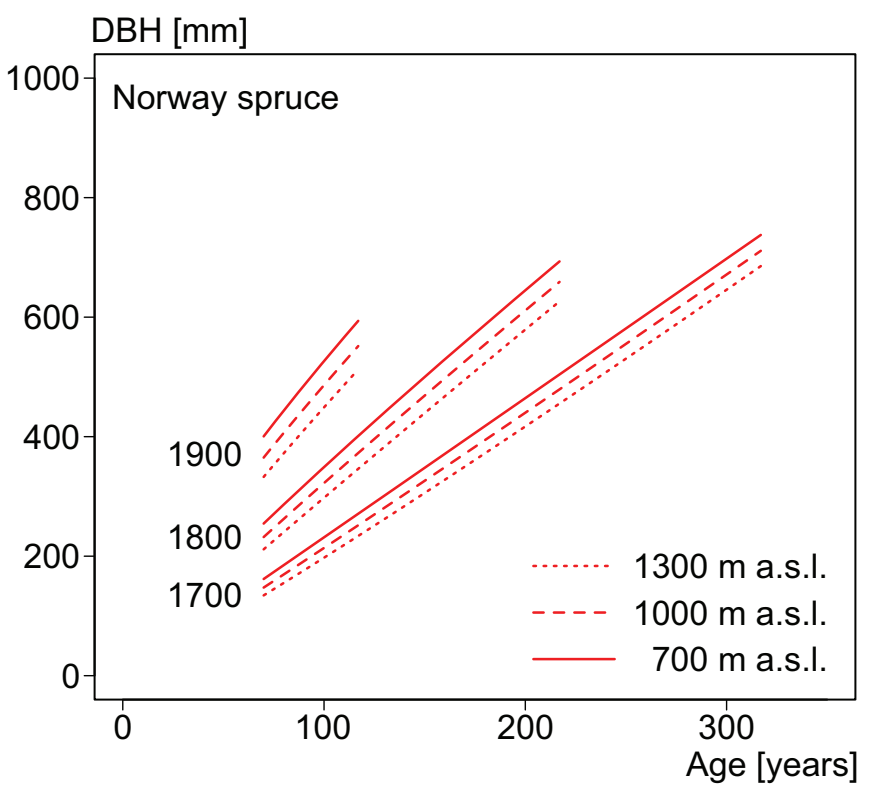

growth with fluctuating de Martonne indices (see Supplementary Fig. S1 ${ }^{1}$ ). This finding makes it clear that there is a high regional variation in precipitation and aridity and that these variations must be considered when analyzing growth trends in mountain areas (Körner 2007).

Figure 9 may contribute to a better understanding of the species-specific growth behaviour, especially the relative gain of silver fir and European beech compared with Norway spruce. Considering only the temperature changes, European beech and silver fir should mainly gain in growth under climate warming, whereas Norway spruce should mainly lose in growth. This change in the ranking among the species is in line with our findings. The growth increase of Norway spruce, despite detrimental mean temperature effects, might result from other positive effects such as extended growing season, fertilizing deposition, or increase of the atmospheric $\mathrm{CO}_{2}$ concentration. In addition, at positions 2 and 3 in Fig. 9, the mixing of Norway spruce with European beech and silver fir may result in a competition reduc- 
Table 9. Results of fitting the linear mixed-effect model from eq. 4 to the Norway spruce data.

\begin{tabular}{|c|c|c|c|c|}
\hline Fixed-effect variable & $\begin{array}{l}\text { Fixed-effect } \\
\text { parameter }\end{array}$ & Estimate & SE & $p$ \\
\hline & $a_{0}$ & $-5.994 \times 10^{0}$ & $1.699 \times 10^{0}$ & 0.0004 \\
\hline $\ln (\mathrm{AGE})$ & $a_{1}$ & $2.925 \times 10^{0}$ & $3.298 \times 10^{-2}$ & $<0.0001$ \\
\hline DYEAR & $a_{2}$ & $4.232 \times 10^{-3}$ & $9.516 \times 10^{-4}$ & $<0.0002$ \\
\hline ALT & $a_{3}$ & $3.575 \times 10^{-5}$ & $3.167 \times 10^{-4}$ & 0.9102 \\
\hline deMARTONNE & $a_{4}$ & $-8.327 \times 10^{-2}$ & $1.489 \times 10^{-2}$ & $<0.0000$ \\
\hline $\ln (\mathrm{AGE}) \times$ DYEAR & $a_{5}$ & $-1.188 \times 10^{-3}$ & $1.767 \times 10^{-5}$ & $<0.0001$ \\
\hline $\ln (\mathrm{AGE}) \times \mathrm{ALT}$ & $a_{6}$ & $1.238 \times 10^{-4}$ & $5.084 \times 10^{-6}$ & $<0.0001$ \\
\hline $\ln ($ AGE $) \times$ deMARTONNE & $a_{7}$ & $1.150 \times 10^{-4}$ & $3.265 \times 10^{-5}$ & 0.0004 \\
\hline DYEAR $\times$ ALT & $a_{8}$ & - & - & - \\
\hline DYEAR $\times$ deMARTONNE & $a_{9}$ & $5.011 \times 10^{-5}$ & $8.304 \times 10^{-6}$ & $<0.0001$ \\
\hline \multirow[t]{6}{*}{ ALT $\times$ deMARTONNE } & $a_{10}$ & $-8.163 \times 10^{-6}$ & $2.763 \times 10^{-6}$ & 0.0034 \\
\hline & $\begin{array}{l}\text { Random } \\
\text { effect }\end{array}$ & SD & & \\
\hline & $b_{i}$ & 0.3165 & & \\
\hline & $b_{i j}$ & 0.2394 & & \\
\hline & Residual & SD & & \\
\hline & $\varepsilon_{i j k}$ & 0.1231 & & \\
\hline
\end{tabular}

Fig. 7. Elevation-dependent changes of the growth of silver fir in the last 300 years (for explanation of lines, see Fig. 6). See Supplementary Fig. S2 for changes depending on the de Martonne aridity index. ${ }^{1}$ [Colour online.]

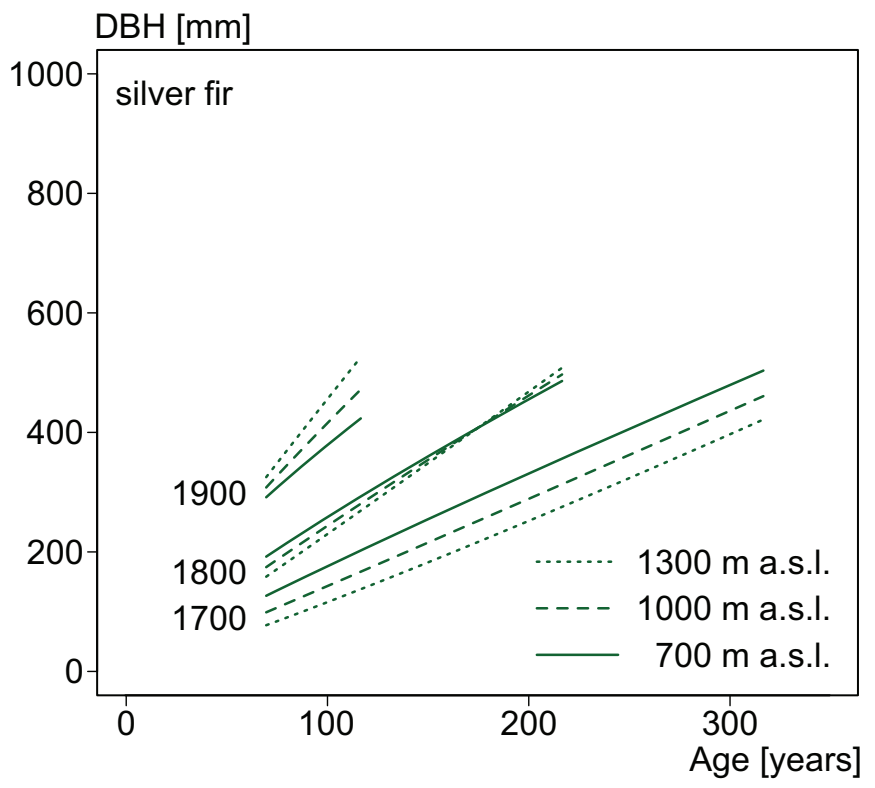

tion or even facilitation compared with growth in intraspecific neighbourhoods (Pretzsch and Forrester 2017, pp. 146-148). Stands of Norway spruce cultivated beyond the natural niche (position 3) may be increasingly endangered by drought and by competition from silver fir and European beech.

Temperature and precipitation measurements over the last decades showed a significant increase in temperature but no significant trend in annual precipitation in the mountain regions of Europe (e.g., Auer et al. 2007; Büntgen et al. 2011; Hilmers et al. 2019). The growth of beech increased because of this warming and the simultaneously high amount of precipitation at higher elevations (Fig. 8). This is in line with the work of Aertsen et al. (2014) and Tegel et al. (2014), who also discussed an increase in growth of beech. Nevertheless, beech faces challenging environmental changes, especially in mountainous areas. Environmental changes in the alpine regions are mainly characterized by acid and nitrogen depositions and $\mathrm{O}_{3}$ pollution (Brang 1998; Flückiger and Braun 1999; Smidt and Herman 2004). Muzika et al. (2004), for example, found significant negative correlations between air pollutants $\left(\mathrm{O}_{3}\right.$, nitrogen dioxide $\left(\mathrm{NO}_{2}\right)$, and $\left.\mathrm{SO}_{2}\right)$ and the growth of beech and spruce in the Carpathian Mountains. In addition, there are natural influences due to climate change such as late frost events and drought stress (Dittmar et al. 2003; Jump et al. 2006; Bontemps et al. 2009), as well as biotic diseases such as fungal infestation (Cherubini et al. 2002). However, so far, the growth-accelerating effects of the climate warming seem to outweigh negative effects in mixed mountain forests (Tognetti et al. 2014).

For silver fir, our results (Fig. 7) are in line with several studies (e.g., Uhl et al. 2013; Büntgen et al. 2014; Bosela et al. 2018) that demonstrated an unprecedented increase in productivity of silver fir in Central European forests following the reduction in air pollutants since the 1980s in combination with a warmer, but not drier, climate in the Alps. However, a recent Europe-wide study on the growth of silver fir throughout the Holocene (Büntgen et al. 2014) describes increasing radial growth in the Italian Alps and the Apennines until the turn of the millennium, but not beyond. Bosela et al. (2018) showed that silver fir populations in the southern parts of the Alps may have recently experienced a growth limitation due to drought. Silver fir populations close to the Mediterranean distribution limit already show a drought-induced growth depression, which will become even more critical in a warmer and drier future (Antonucci et al. 2019).

Remarkably, our results for spruce (Fig. 6) show a steady increase in growth rates since the 17th century, even at lower elevations ( $\sim 800 \mathrm{~m}$ a.s.1.); this is similar to the findings by Schurman et al. (2019). However, the increase was lower than for the other two species (Fig. 5). This suggests that in the mixed mountain forests of Europe, spruce, in relation to beech and silver fir, loses in the face of competition probably because of its lower adaptation to drought compared with the associated species and their increasing vitality and competitiveness. Cocozza et al. (2016) observed that the phenology of cambial cell production in spruce is highly variable and plastic with elevation, enabling this species to occupy sites with contrasting climatic conditions, namely high elevations and cold sites. However, further climate warming, natural disturbance events such as strong winds, bark beetle out- 
Table 10. Results of fitting the linear mixed-effect model from eq. 4 to the silver fir data.

\begin{tabular}{|c|c|c|c|c|}
\hline Fixed-effect variable & $\begin{array}{l}\text { Fixed-effect } \\
\text { parameter }\end{array}$ & Estimate & SE & $p$ \\
\hline & $a_{0}$ & $-9.414 \times 10^{0}$ & $1.992 \times 10^{0}$ & $<0.0001$ \\
\hline $\ln (\mathrm{AGE})$ & $a_{1}$ & $2.319 \times 10^{0}$ & $3.872 \times 10^{-2}$ & $<0.0000$ \\
\hline DYEAR & $a_{2}$ & $6.548 \times 10^{-3}$ & $1.089 \times 10^{-3}$ & $<0.0000$ \\
\hline ALT & $a_{3}$ & $-1.084 \times 10^{-2}$ & $2.679 \times 10^{-3}$ & $<0.0001$ \\
\hline deMARTONNE & $a_{4}$ & $4.765 \times 10^{-2}$ & $1.793 \times 10^{-2}$ & 0.0081 \\
\hline $\ln (\mathrm{AGE}) \times$ DYEAR & $a_{5}$ & $-9.351 \times 10^{-4}$ & $2.092 \times 10^{-5}$ & $<0.0001$ \\
\hline $\ln (\mathrm{AGE}) \times \mathrm{ALT}$ & $a_{6}$ & $3.483 \times 10^{-4}$ & $5.217 \times 10^{-6}$ & $<0.0001$ \\
\hline $\ln (\mathrm{AGE}) \times$ deMARTONNE & $a_{7}$ & $-7.440 \times 10^{-4}$ & $4.115 \times 10^{-5}$ & $<0.0001$ \\
\hline DYEAR $\times$ ALT & $a_{8}$ & $5.022 \times 10^{-6}$ & $1.447 \times 10^{-6}$ & 0.0006 \\
\hline DYEAR $\times$ deMARTONNE & $a_{9}$ & $-2.401 \times 10^{-5}$ & $9.662 \times 10^{-6}$ & 0.0132 \\
\hline \multirow[t]{6}{*}{ ALT $\times$ deMARTONNE } & $a_{10}$ & 一 & - & - \\
\hline & $\begin{array}{l}\text { Random } \\
\text { effect }\end{array}$ & SD & & \\
\hline & $b_{i}$ & 0.1718 & & \\
\hline & $b_{i j}$ & 0.3114 & & \\
\hline & Residual & SD & & \\
\hline & $\varepsilon_{i j k}$ & 0.1582 & & \\
\hline
\end{tabular}

Fig. 8. Elevation-dependent changes of the growth of European beech in the last 300 years (for explanation of lines, see Fig. 6). See Supplementary Fig. S3 for changes depending on the de Martonne aridity index. ${ }^{1}$ [Colour online.]

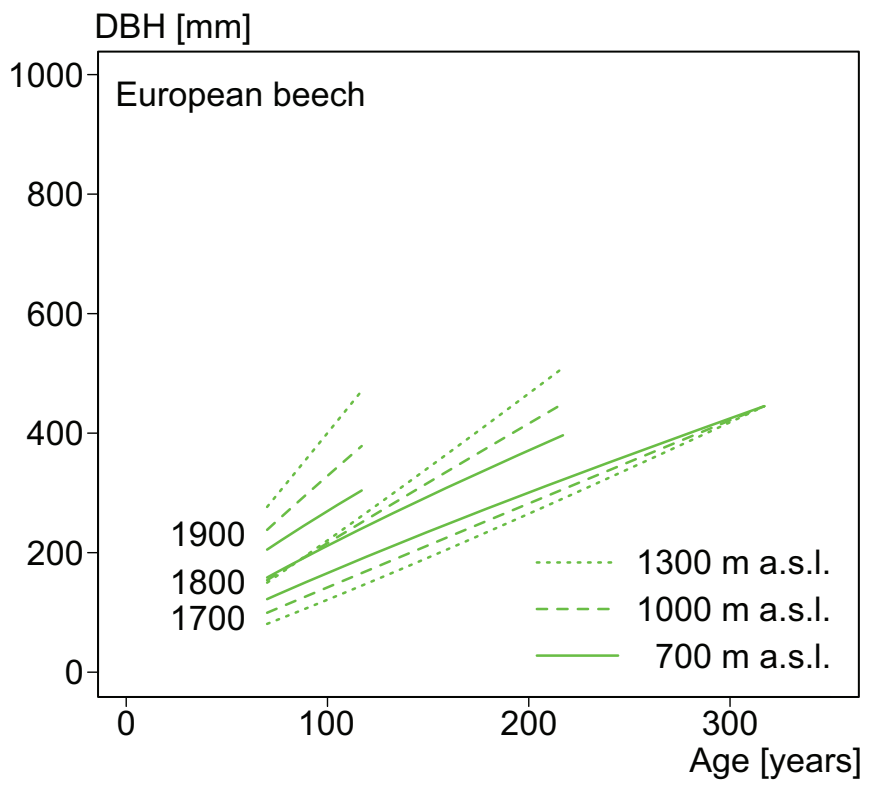

breaks, and summer droughts will pose great challenges for spruce, especially in monolayered stands at low elevations (Lévesque et al. 2013; Zang et al. 2014; Seidl et al. 2017) and probably less seriously in mountain areas with cooler temperatures and higher precipitations.

Hilmers et al. (2019) showed that the stand-level productivity of mixed mountain forests was stable, in terms of volume increments over the last 30 years. However, they also showed that the tree species involved (beech, spruce, and fir) showed remarkably different volume increments at the stand level. Spruce showed a significant decline in productivity, whereas silver fir showed significant productivity gains. Beech showed unchanged volume increments over several decades. In summary, the stand-level productivity remained rather stable because losses of one species were compensated by gains of the others.
Our results deal with the individual tree level and show that the mean increment, as well as the age trend of all three tree species, has increased steadily since the 17th century. Productivity at the stand level, however, is not only driven by the productivity of the individual trees, but also depends on stand structure (e.g., density and size distribution) (Forrester 2019). It is likely that the sampled dominant trees benefited more from the extended growing seasons and the effect of $\mathrm{CO}_{2}$ fertilization (Kulakowski et al. 2011; Pretzsch et al. 2014) than the subdominant and suppressed individuals that were limited by light. It is possible that spruce trees from intermediate and suppressed social classes may have suffered significantly or even died from the competitive shift among the three tree species and thus the productivity of Norway spruce at a stand level may have decreased as reported by Hilmers et al. (2019).

The revealed growth trends may be overestimated because of a bias that may be caused by sampling dominant trees that were subdominant in the more distant past. Their growth trend may partly be an effect of a change from a subdominant and slowgrowing social position to a dominant and fast-growing social position within the population. We tried to reduce this potential sampling bias as described in section 2.1.2. Thus, the statements about the absolute growth trend of Norway spruce, silver fir, and European beech should be used cautiously and need further substantiation. However, the general findings of a positive growth trend, the relationships among the tree species, and the elevationspecific growth changes would hardly be modified by a biased sampling. Therefore, we think that, unlike the statements about the absolute trends, the relative changes of growth are well substantiated by our study.

\subsection{Relevance and perspectives}

The study by Hilmers et al. (2019) about the stand growth of mixed mountain forests covered many of the plots that were also included in our study of the individual tree growth. Hilmers et al. (2019) showed that the stand growth in total has hardly changed over the last 30 years (Hilmers et al. 2019). Any growth decline or dropout of subdominant trees may have been compensated by the persevering growth of the dominant trees shown in our study. A temporal growth decline of silver fir due to $\mathrm{SO}_{2}$ emissions in 1970-1990, for instance, was compensated by the growth of Norway spruce, which is more resistant to $\mathrm{SO}_{2}$ pollution. Growth losses due to $\mathrm{O}_{3}$ emissions may be compensated by the other two 
Table 11. Results of fitting the linear mixed-effect model from eq. 4 to the European beech data.

\begin{tabular}{|c|c|c|c|c|}
\hline Fixed-effect variable & $\begin{array}{l}\text { Fixed-effect } \\
\text { parameter }\end{array}$ & Estimate & SE & $p$ \\
\hline & $a_{0}$ & $1.048 \times 10^{0}$ & $1.822 \times 10^{0}$ & 0.5653 \\
\hline $\ln (\mathrm{AGE})$ & $a_{1}$ & $1.363 \times 10^{0}$ & $3.650 \times 10^{-2}$ & $<0.0001$ \\
\hline DYEAR & $a_{2}$ & $3.231 \times 10^{-4}$ & $1.001 \times 10^{-3}$ & 0.7469 \\
\hline ALT & $a_{3}$ & $-1.161 \times 10^{-2}$ & $1.809 \times 10^{-3}$ & $<0.0001$ \\
\hline deMARTONNE & $a_{4}$ & $1.715 \times 10^{-2}$ & $2.637 \times 10^{-3}$ & $<0.0001$ \\
\hline $\ln ($ AGE $) \times$ DYEAR & $a_{5}$ & $-4.400 \times 10^{-4}$ & $1.974 \times 10^{-5}$ & $<0.0001$ \\
\hline $\ln (\mathrm{AGE}) \times \mathrm{ALT}$ & $a_{6}$ & $4.491 \times 10^{-4}$ & $5.246 \times 10^{-6}$ & $<0.0001$ \\
\hline $\ln ($ AGE $) \times$ deMARTONNE & $a_{7}$ & $-9.574 \times 10^{-4}$ & $3.679 \times 10^{-5}$ & $<0.0001$ \\
\hline DYEAR $\times$ ALT & $a_{8}$ & $5.871 \times 10^{-6}$ & $9.911 \times 10^{-7}$ & $<0.0001$ \\
\hline DYEAR × deMARTONNE & $a_{9}$ & - & - & - \\
\hline \multirow[t]{6}{*}{ ALT $\times$ deMARTONNE } & $a_{10}$ & $-1.150 \times 10^{-5}$ & $2.054 \times 10^{-6}$ & $<0.0001$ \\
\hline & $\begin{array}{l}\text { Random } \\
\text { effect }\end{array}$ & SD & & \\
\hline & $b_{i}$ & 0.1749 & & \\
\hline & $b_{i j}$ & 0.2899 & & \\
\hline & Residual & SD & & \\
\hline & $\varepsilon_{i j k}$ & 0.1622 & & \\
\hline
\end{tabular}

nent was excluded from the final model.

Fig. 9. Temperature niches of Norway spruce, silver fir, and European beech according to Kölling (2007) and effects of climate warming (grey hatched stripes with arrows pointing to the right to warmer conditions) in mixed mountain forests in Europe. Positions 1-3 represent the constellation of the three species at high, middle, and low elevations, respectively.

\section{relative growth}

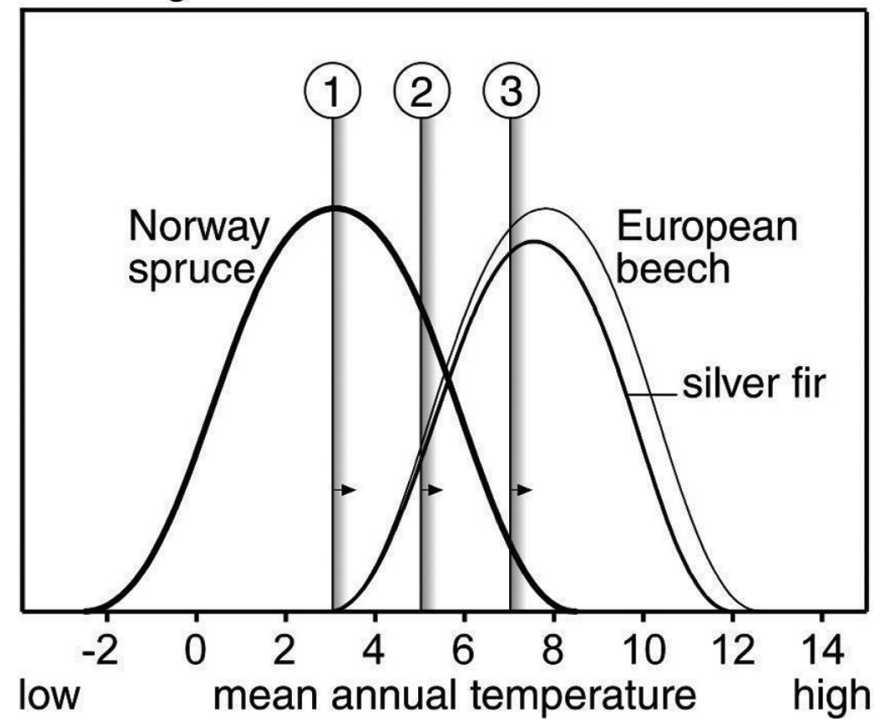

species. The particular drought-sensitive and isohydric sit-andwait behaviour of Norway spruce might be counteracted by the anisohydric behaviour of European beech that continues growing unless water scarcity causes hydraulic failure (e.g., Klein 2014).

Our results suggest that this balance and growth stability due to tree species diversity may be compromised in the future. Especially at lower elevations, where Norway spruce grew optimally in the past, drought may reduce its contribution to stand growth in the future. One additional reason for this may be the relative loss in competitiveness compared with silver fir and European beech, which are better adapted to drought. We hypothesize that a key life-history trade-off will be how these three species trade off resources devoted to drought (future limiting factor) versus radiation (main limiting factor over thousands of years) and that this trade-off may shift with ontogeny. In addition, bark beetle outbreaks and storm damage can reduce the share of spruce in lowelevation forests.

The contradictory findings in this study that the increment cores of dominant trees of Norway spruce showed increasing growth but the stand growth of Norway spruce is decreasing on the same plots (Hilmers et al. 2019) may be explained by the decreasing abundance of Norway spruce in the stands. This decreasing abundance of Norway spruce may be a result of the growth trends that are more positive for silver fir and European beech and that may cause a relative competitive disadvantage for subdominant spruces. However, this is speculative and needs further research into the contribution of different species and size classes of individuals to the stand growth as recently pointed out by Torresan et al. (2020).

\subsection{Silvicultural and ecological implications}

The long-term growth trajectories of Norway spruce in relation to silver fir and European beech suggest a relative advantage of fir and beech at the expense of spruce. The growth reduction of spruce in relation to fir and beech means a loss of fitness. At lower elevations, Norway spruce is limited by drought events and bark beetle; at higher elevations, it is impaired by the growth acceleration of neighbouring silver fir and European beech in mixed mountain stands. Except in the high-montane and subalpine zone, silver fir and European beech will probably benefit from natural conditions (i.e., without silvicultural promotion) and gradually replace the role that Norway spruce had in the past. At lower elevations, Norway spruce will be restrained to cold sites where fir and beech may be limited by late frost. Norway spruce may also have a chance to establish under disturbances that cause abrupt opening of the previously dense canopy and exposure of the soil. In addition, spruce regeneration depends on nurse logs in some stand conditions (Stroheker et al. 2018). Where there is not yet impeding competition by already established fir and beech, spruce regeneration may benefit from its ability to quickly establish on open mineral soil and establish successfully, although the further development may be questionable because of the previously mentioned restrictions.

Norway spruce can be only partly replaced by silver fir. Forest management may be interested in keeping a significant portion of Norway spruce in mountain forests, for example, because of its high appreciation by forest industry and its contribution to ero- 
sion protection due to its canopy closure in the winter period when beech is leafless. Norway spruce can also be promoted on sites where silver fir may fail to regenerate because of browsing pressure (Kupferschmid 2018).

Although Norway spruce may have no future at lower elevations because of interspecific competition, warming, drought, and bark beetle damage, it may be promoted by silvicultural measures at higher elevations. Natural regeneration may be successful by opening the canopy of previously fully stocked stands in seed years. Planting may also be an option, for example, in combination with opening for skyline crane harvest operations. However, the strengthening of silver fir and European beech will require continuous promotion of Norway spruce after successful establishment, especially in lower and middle elevations.

Mountain forests in Europe provide diverse ecosystem services such as protection against natural hazards, wood, water purification, biodiversity, and recreation areas. The mixed mountain forests analyzed in this study fulfil many ecosystem services better than monocultures. Therefore, forest management should strive to keep them stable and even transform homogenous forest stands into selection forests or other kinds of forests with rich composition and structure.

The sustainability of mixed mountain forests in wood production and other ecosystem services is mainly based on the tree species diversity. Species diversity can mean risk distribution in view of abiotic and biotic disturbances, stability of growth, and permanent protection function (soil erosion, avalanches, and flooding). The weakening of one species by environmental change may be successfully compensated by promoting and transitioning to more suitable tree species such as sycamore maple (Acer pseudoplatamus L.) or European chestnut (Castanea sativa Mill.). Introduction of alien species such as Douglas-fir (Pseudotsuga menziesii (Mirb.) Franco) is quite controversial, as this will conflict with the objective of managing mountain forests less intensively or leaving them in a more natural state.

\section{Conclusions}

Tree-ring analyses revealed significant elevation-specific growth changes of Norway spruce, silver fir, and European beech in European mixed mountain forests during the last three centuries. The growth of Norway spruce lags behind that of fir and beech, especially at lower and middle elevations. However, for the maintenance of production, biodiversity, recreation, and essential protection services of mountain forests, silvicultural concepts should ensure the promotion of spruce on sites suitable for future climatic conditions while facilitating the establishment of other better adapted tree species where spruce might become at risk.

A potential silvicultural challenge in these forests may be to keep at least a minor portion of Norway spruce because of its significant provision of various ecosystem services. In particular, the mixed mountain forests with high portions of Norway spruce should be converted to more diverse stands by regulating the natural regeneration or by planting in favour of, for example, silver fir, European beech, sycamore maple, or Douglas-fir for stabilization of growth, productivity, and other ecosystem services.

\section{Acknowledgement}

We acknowledge networking support by the COST (European Cooperation in Science and Technology) Action CLIMO (ClimateSmart Forestry in Mountain Regions - CA15226) and financial support from the EU Framework Programme for Research and Innovation HORIZON 2020. This publication is part of a project that has received funding from the European Union's HORIZON 2020 Research and Innovation Programme under the Marie Skłodowska-Curie grant agreement No. 778322. We also thank the European Union for funding the project "Mixed species forest management. Lowering risk, increasing resilience (REFORM)" (No. 2816ERA02S under the framework of Sumforest ERA-Net). Further, we thank the Bayerische Staatsforsten (BaySF) for providing the observational plots and the Bavarian State Ministry of Food, Agriculture, and Forestry for permanent support of the project W 07 "Long-term experimental plots for forest growth and yield research" (No. 7831-26625-2017). The study was also supported by the grant "EVA4.0", No. CZ.02.1.01/0.0/0.0/16_019/0000803 and partially supported by the SRDA via project No. APVV-16-0325. Tzvetan Zlatanov was supported by the Bulgarian National Service Fund (BNSF) via project No. DCOST 01/3/19.10.2018. Finally, we thank two anonymous reviewers for their constructive criticism.

\section{References}

Aertsen, W., Janssen, E., Kint, V., Bontemps, J.D., Van Orshoven, J., and Muys, B. 2014. Long-term growth changes of common beech (Fagus sylvatica L.) are less pronounced on highly productive sites. For. Ecol. Manage. 312: 252-259. doi:10.1016/j.foreco.2013.09.034.

Allen, C.D., Breshears, D.D., and McDowell, N.G. 2015. On underestimation of global vulnerability to tree mortality and forest die-off from hotter drought in the Anthropocene. Ecosphere, 6: 1-55. doi:10.1890/ES15-00203.1.

Ammer, C. 1996. Impact of ungulates on structure and dynamics of natural regeneration of mixed mountain forests in the Bavarian Alps. For. Ecol. Manage. 88(1-2): 43-53. doi:10.1016/S0378-1127(96)03808-X.

Antonucci, S., Rossi, S., Lombardi, F., Marchetti, M., and Tognetti, R. 2019. Influence of climatic factors on silver fir xylogenesis along the Italian Peninsula. IAWA J. 40: 259-275. doi:10.1163/22941932-40190222.

Assmann, E. 1961. Waldertragskunde. Organische Produktion, Struktur, Zuwachs und Ertrag von Waldbeständen. BLV Verlagsgesellschaft, München, Bonn, Wien.

Auer, I., Böhm, R., Jurkovic, A., Lipa, W., Orlik, A., Potzmann, R., et al. 2007. HISTALP - historical instrumental climatological surface time series of the Greater Alpine Region. Int. J. Climatol. 27: 17-46. doi:10.1002/joc.1377.

Bebi, P., Kienast, F., and Schönenberger, W. 2001. Assessing structures in mountain forests as a basis for investigating the forests' dynamics and protective function. For. Ecol. Manage. 145(1-2): 3-14. doi:10.1016/S0378-1127(00)00570-3.

Bielak, K., Dudzińska, M., and Pretzsch, H. 2014. Mixed stands of Scots pine (Pinus sylvestris L.) and Norway spruce [Picea abies (L.) Karst] can be more productive than monocultures. Evidence from over 100 years of observation of long-term experiments. For. Syst. 23: 573-589. doi:10.5424/fs/2014233-06195.

Bircher, N., Cailleret, M., Zingg, A., and Bugmann, H. 2016. Potenzielle Grundflächenveränderungen auf Bestandesebene im Klimawandel. In Wald im Klimawandel-Grundlagen für Adaptionsstrategien. Haupt. pp. 157-171.

Bontemps, J.-D., Hervé, J.-C., and Dhôte, J.-F. 2009. Long-term changes in forest productivity: a consistent assessment in even-aged stands. For. Sci. 55: 549564. doi:10.1093/forestscience/55.6.549.

Bosela, M., Lukac, M., Castagneri, D., Sedmák, R., Biber, P., Carrer, M., et al. 2018. Contrasting effects of environmental change on the radial growth of cooccurring beech and fir trees across Europe. Sci. Total Environ. 615: 14601469. doi:10.1016/j.scitotenv.2017.09.092. PMID:29055588.

Bosela, M., Kulla, L., Roessiger, J., Šebeň, V., Dobor, L., Büntgen, U., and Lukac, M. 2019. Long-term effects of environmental change and species diversity on tree radial growth in a mixed European forest. For. Ecol. Manage. 446: 293303. doi:10.1016/j.foreco.2019.05.033.

Brang P. 1998. Sanasilva-Bericht 1997: Zustand und Gefährdung des Schweizer Waldes-eine Zwischenbilanz nach 15 Jahren Waldschadenforschung. Bundesamt für Umwelt Wald und Landschaft; Eidgenössische Forschungsanstalt für Wald Schnee und Landschaft.

Büntgen, U., Tegel, W., Nicolussi, K., McCormick, M., Frank, D., Trouet, V., et al. 2011. 2500 Years of European climate variability and human susceptibility. Science, 331: 578-582. doi:10.1126/science.1197175. PMID:21233349.

Büntgen, U., Tegel, W., Kaplan, J.O., Schaub, M., Hagedorn, F., Bürgi, M., et al. 2014. Placing unprecedented recent fir growth in a European-wide and Holocene-long context. Front. Ecol. Environ. 12: 100-106. doi:10.1890/130089.

Burnham, K.P., and Anderson, D.R. 2004. Multimodel inference: understanding AIC and BIC in model selection. Sociol. Methods Res. 33(2): 261-304. doi:10. 1177/0049124104268644.

Burschel, P., and Huss, J. 1987. Grundriß des Waldbaus. Pareys Studientexte 49, Hamburg, Berlin.

Cherubini, P., Fontana, G., Rigling, D., Dobbertin, M., Brang, P., and Innes, J.L. 2002. Tree-life history prior to death: two fungal root pathogens affect treering growth differently. J. Ecol. 90: 839-850. doi:10.1046/j.1365-2745.2002. 00715.x.

Cocozza, C., Palombo, C., Tognetti, R., La Porta, N., Anichini, M., Giovannelli, A., and Emiliani, G. 2016. Monitoring intra-annual dynamics of wood formation with microcores and dendrometers in Picea abies at two different altitudes. Tree Physiol. 36: 832-846. doi:10.1093/treephys/tpw009. PMID:26941291.

de Martonne, E. 1926. Une Nouvelle Fonction Climatologique: L'Indice d'Aridite. [A new climatological function: the aridity index.] La Météorologie, 2: 449458 
Dittmar, C., Zech, W., and Elling, W. 2003. Growth variations of common beech (Fagus sylvatica L.) under different climatic and environmental conditions in Europe - a dendroecological study. For. Ecol. Manage. 173: 63-78. doi:10. 1016/S0378-1127(01)00816-7.

Ellenberg, H., and Leuschner, C. 2010. Vegetation Mitteleuropas mit den Alpen: in ökologischer, dynamischer und historischer Sicht. Vol. 8104. Ullmer UTB.

Ellenberg, H., Mayer, R., and Schauermann, J. 1986. Ökoystemforschung - Ergebnisse des Sollingprojektes. Ulmer Verlag, Stuttgart

Elling, W., Dittmar, C., Pfaffelmoser, K., and Rötzer, T. 2009. Dendroecological assessment of the complex causes of decline and recovery of the growth of silver fir (Abies alba Mill.) in Southern Germany. For. Ecol. Manage. 257(4): 1175-1187. doi:10.1016/j.foreco.2008.10.014

Evans, G.C. 1972. The quantitative analysis of plant growth, studies in ecology. Vol. 1. Blackwell Scientific Publications, Oxford. 734 S.

Flückiger, W., and Braun, S. 1999. Wie geht es unserem Wald? Untersuchungen in Walddauerbeobachtungsflächen von 1984 bis 1998. Institut für Angewandte Pflanzenbiologie (IAP), Schönenbuch.

Forrester, D.I. 2019. Linking forest growth with stand structure: tree size inequality, tree growth or resource partitioning and the asymmetry of competition. For. Ecol. Manage. 447: 139-157. doi:10.1016/j.foreco.2019.05.053.

Forrester, D.I., and Albrecht, A.T. 2014. Light absorption and light-use efficiency in mixtures of Abies alba and Picea abies along a productivity gradient. For. Ecol. Manage. 328: 94-102. doi:10.1016/j.foreco.2014.05.026.

Hanewinkel, M., Cullmann, D.A., Schelhaas, M.-J., Nabuurs, G.-J., and Zimmermann, N.E. 2013. Climate change may cause severe loss in the economic value of European forest land. Nat. Clim. Change, 3: 203-207. doi:10. 1038/nclimate1687.

Harris, I., Jones, P.D., Osborn, T.J., and Lister, D.H. 2014. Updated high-resolution grids of monthly climatic observations - the CRU TS3.10 dataset. Int. J. Climatol. 34: 623-642. doi:10.1002/joc.3711.

Hilmers, T., Avdagić, A., Bartkowicz, L., Bielak, K., Binder, F., Bončina, A., et al. 2019. The productivity of mixed mountain forests comprised of Fagus sylvatica, Picea abies, and Abies alba across Europe. Forestry (Lond.), 92: 512-522. doi:10.1093/forestry/cpz035.

Hutchinson, G.E. 1957. Concluding remarks. Cold Spring Harb. Symp. Quant. Biol. 22: 415-427. doi:10.1101/SQB.1957.022.01.039.

IUSS Working Group WRB. 2015. World reference base for soil resources 2014. International soil classification system for naming soils and creating legends for soil maps. Update 2015. World Soil Resources Reports No. 106. Food and Agriculture Organization of the United Nations, Rome. Available from http:// www.fao.org/3/i3794en/I3794en.pdf.

Jensen, A.M. 1983. Growth of silver fir (Abies alba Mill.) compared with the growth of Norway spruce (Picea abies (L.) Karst.) in pure and mixed stands on sandy soils in the western parts of Denmark. Dep. Forestry, Royal Vet. Agr. Univ. Rep. 14.

Jolly, W.M., Dobbertin, M., Zimmermann, N.E., and Reichstein, M. 2005. Divergent vegetation growth responses to the 2003 heat wave in the Swiss Alps. Geophys. Res. Lett. 32. doi:10.1029/2005GL023252.

Jucker, T., Bouriaud, O., and Coomes, D.A. 2015. Crown plasticity enables trees to optimize canopy packing in mixed-species forests. Funct. Ecol. 29(8): 10781086. doi:10.1111/1365-2435.12428.

Jump, A.S., Hunt, J.M., and Peñuelas, J. 2006. Rapid climate change-related growth decline at the southern range edge of Fagus sylvatica. Glob. Change Biol. 12: 2163-2174. doi:10.1111/j.1365-2486.2006.01250.x.

Kauppi, P.E., Posch, M., and Pirinen, P. 2014. Large impacts of climatic warming on growth of boreal forests since 1960. PLoS One, 9(11): e111340. doi:10.1371/ journal.pone.0111340. PMID:25383552.

Khurshid-Alam, F.C. 1972. Distribution of precipitation in mountainous areas of West Pakistan (isohyetal rainfall maps). WMO Distribution of Precipitation in Mountainous Areas, Vol. 2.

Klein, T. 2014. The variability of stomatal sensitivity to leaf water potential across tree species indicates a continuum between isohydric and anisohydric behaviours. Funct. Ecol. 28(6): 1313-1320. doi:10.1111/1365-2435.12289.

Kölling, C. 2007. Klimahüllen für 27 Waldbaumarten. AFZ-DerWald, 23: 12421245.

Körner, C. 2003. Alpine plant life: functional plant ecology of high mountain ecosystems. Springer-Verlag, Berlin, Heidelberg. doi:10.1007/978-3-642-18970-8.

Körner, C. 2007. The use of 'altitude' in ecological research. Trends Ecol. Evol. 22(11): 569-574. doi:10.1016/j.tree.2007.09.006.

Kramer H. 1988. Waldwachstumslehre. Paul Parey, Hamburg, Berlin.

Kräuchi, N., Brang, P., and Schönenberger, W. 2000. Forests of mountainous regions: gaps in knowledge and research needs. For. Ecol. Manage. 132(1): 73-82. doi:10.1016/S0378-1127(00)00382-0.

Kulakowski, D., Bebi, P., and Rixen, C. 2011. The interacting effects of land use change, climate change and suppression of natural disturbances on landscape forest structure in the Swiss Alps. Oikos, 120: 216-225. doi:10.1111/j.16000706.2010.18726.x.

Kupferschmid, A.D. 2018. Selective browsing behaviour of ungulates influences the growth of Abies alba differently depending on forest type. For. Ecol. Manage. 429: 317-326. doi:10.1016/j.foreco.2018.06.046.

Larsen, J.B., Yang, W.V., and Tiedemann, A.V. 1990. Effects of ozone on gas exchange, frost resistance, flushing and growth of different provenances of
European silver fir (Abies alba Mill.). Eur. J. For. Pathol. 20(4): 211-218. doi:10. 1111/j.1439-0329.1990.tb01132.x.

Lauscher, F. 1976. Weltweite typen der hohenabhangigkeit des niederschlags. Wetter und Leben, 28: 80-90.

Leuschner C. 2009. Die Trockenheitsempfindlichkeit der Rotbuche vor dem Hintergrund des prognostizierten Klimawandels. Jahrbuch der Akademie der Wissenschaften zu Göttingen. pp. 281-296.

Lévesque, M., Saurer, M., Siegwolf, R., Eilmann, B., Brang, P., Bugmann, H., and Rigling, A. 2013. Drought response of five conifer species under contrasting water availability suggests high vulnerability of Norway spruce and European larch. Glob. Change Biol. 19: 3184-3199. doi:10.1111/gcb.12268. PMID: 23712589.

Lindner, M., Maroschek, M., Netherer, S., Kremer, A., Barbati, A., Garcia-Gonzalo, J., et al. 2010. Climate change impacts, adaptive capacity, and vulnerability of European forest ecosystems. For. Ecol. Manage. 259(4): 698709. doi:10.1016/j.foreco.2009.09.023.

Lyr, H., Fiedler, H.J., and Tranquillini, W. 1992. Physiologie und Ökologie der Gehölze. G. Fischer Verlag, Jena.

Magin R. 1959. Struktur und Leistung mehrschichtiger Mischwälder in den bayerischen Alpen. Mitt Staatsforstverwaltung Bayerns 30.

Matyssek, R., Wieser, G., Ceulemans, R., Rennenberg, H., Pretzsch, H., Haberer, K., and Oßwald, W. 2010. Enhanced ozone strongly reduces carbon sink strength of adult beech (Fagus sylvatica) - resume from the free-air fumigation study at Kranzberg Forest. Environ. Pollut. 158(8): 2527-2532. doi:10.1016/j.envpol.2010.05.009. PMID:20570421.

Menzel, A., and Fabian, P. 1999. Growing season extended in Europe. Nature, 397(6721): 659-659. doi:10.1038/17709.

Mina, M., Huber, M.O., Forrester, D.I., Thürig, E., and Rohner, B. 2018. Multiple factors modulate tree growth complementarity in central European mixed forests. J. Ecol. 106: 1106-1119. doi:10.1111/1365-2745.12846.

Mitscherlich, G. 1971. Wald, Wachstum und Umwelt. 2. Band, Waldklima und wasserhaushalt. JD Sauerländer's Verlag, Frankfurt am Main.

Muzika, R.M., Guyette, R.P., Zielonka, T., and Liebhold, A.M. 2004. The influence of $\mathrm{O}_{3}, \mathrm{NO}_{2}$ and $\mathrm{SO}_{2}$ on growth of Picea abies and Fagus sylvatica in the Carpathian Mountains. Environ. Pollut. 130: 65-71. doi:10.1016/j.envpol.2003. 10.021. PMID:15046841.

Nehrbass-Ahles, C., Babst, F., Klesse, S., Nötzli, M., Bouriaud, O., Neukom, R., et al. 2014. The influence of sampling design on tree-ring based quantification of forest growth. Glob. Change Biol. 20: 2867-2885. doi:10.1111/gcb.12599. PMID:24729489.

Nikolova, P.S., Raspe, S., Andersen, C.P., Mainiero, R., Blaschke, H., Matyssek, R., and Häberle, K.H. 2009. Effects of the extreme drought in 2003 on soil respiration in a mixed forest. Eur. J. For. Res. 128(2): 87-98. doi:10.1007/s10342-0080218-6.

Nogués-Bravo, D., Araújo, M.B., Errea, M.P., and Martinez-Rica, J.P. 2007. Exposure of global mountain systems to climate warming during the 21st Century. Glob. Environ. Change, 17(3-4): 420-428. doi:10.1016/j.gloenvcha.2006.11.007.

Oberhuber, W. 2004. Influence of climate on radial growth of Pinus cembra within the alpine timberline ecotone. Tree Physiol. 24: 291-301. doi:10.1093/treephys/ 24.3.291.

Obojes, N., Meurer, A., Newesely, C., Tasser, E., Oberhuber, W., Mayr, S., and Tappeiner, U. 2018. Water stress limits transpiration and growth of European larch up to the lower subalpine belt in an inner-alpine dry valley. New Phytol. 220: 460-475. doi:10.1111/nph.15348. PMID:30028013.

Panagos, P., Van Liedekerke, M., Jones, A., and Montanarella, L. 2012. European Soil Data Centre: response to European policy support and public data requirements. Land Use Pol. 29: 329-338. doi:10.1016/j.landusepol.2011.07.003.

Pichler, P., and Oberhuber, W. 2007. Radial growth response of coniferous forest trees in an inner Alpine environment to heat-wave in 2003. For. Ecol. Manage. 242: 688-699. doi:10.1016/j.foreco.2007.02.007.

Pinheiro, J., Bates, D., DebRoy, S., Sarkar, D., and R Core Team. 2018. nlme: linear and nonlinear mixed effects models. $\mathrm{R}$ package version 3.1-137. Available from https://CRAN.R-project.org/package $=$ nlme.

Pretzsch, H. 2009. Forest dynamics, growth and yield: from measurement to model. Springer, Berlin, Heidelberg. doi:10.1007/978-3-540-88307-4.

Pretzsch, H., and Forrester, D.I. 2017. Stand dynamics of mixed-species stands compared with monocultures. In Mixed-species forests. Edited by $\mathrm{H}$. Pretzsch, D.I. Forrester, and J. Bauhus. Springer, Berlin. pp. 117-210. doi:10.1007/978-3662-54553-9_4.

Pretzsch, H., Block, J., Dieler, J., Dong, P.H., Kohnle, U., Nagel, J., et al. 2010. Comparison between the productivity of pure and mixed stands of Norway spruce and European beech along an ecological gradient. Ann. For. Sci. 67(7): 712. doi:10.1051/forest/2010037.

Pretzsch, H., Biber, P., Schütze, G., Uhl, E., and Rötzer, T. 2014. Forest stand growth dynamics in Central Europe have accelerated since 1870. Nat. Commun. 5: 4967. doi:10.1038/ncomms5967.

Pretzsch, H., del Río, M., Ammer, C., Avdagic, A., Barbeito, I., Bielak, K., et al. 2015. Growth and yield of mixed versus pure stands of Scots pine (Pinus sylvestris L.) and European beech (Fagus sylvatica L.) analysed along a productivity gradient through Europe. Eur. J. For. Res. 134: 927-947. doi:10.1007| s10342-015-0900-4.

Pretzsch, H., del Rio, M., Biber, P., Arcangeli, C., Bielak, K., Brang, P., et al. 2019. Maintenance of long-term experiments for unique insights into forest 
growth dynamics and trends: review and perspectives. Eur. J. For. Res. 138(1): 165-185. doi:10.1007/s10342-018-1151-y.

Preuhsler, T. 1979. Ertragskundliche Merkmale oberbayerischer BergmischwaldVerjüngungsbestände auf kalkalpinen Standorten im Forstamt Kreuth. Forstl Forschungsber München 45.

QGIS Development Team. 2020. QGIS Geographic Information System. Open Source Geospatial Foundation Project. Available from https://qgis.org/.

R Core Team. 2018. R: a language and environment for statistical computing. R Foundation for Statistical Computing, Vienna, Austria. Available from https://www.R-project.org.

Rothe, A. 1997. Einfluß des Baumartenanteils auf Durchwurzelung, Wasserhaushalt, Stoffhaushalt und Zuwachsleistung eines Fichten-BuchenMischbestandes am Standort Höglwald. Forstl Forschungsber München 163.

Rothe, A., and Binkley, D. 2001. Nutritional interactions in mixed species forests: a synthesis. Can. J. For. Res. 31(11): 1855-1870. doi:10.1139/x01-120.

Saxe, H., Cannell, M.G., Johnsen, Ø., Ryan, M.G., and Vourlitis, G. 2001. Tree and forest functioning in response to global warming. New Phytol. 149(3): 369399. doi:10.1046/j.1469-8137.2001.00057.x.

Schindlbacher, A., Rodler, A., Kuffner, M., Kitzler, B., Sessitsch, A., and Zechmeister-Boltenstern, S. 2011. Experimental warming effects on the microbial community of a temperate mountain forest soil. Soil Biol. Biochem. 43(7): 1417-1425. doi:10.1016/j.soilbio.2011.03.005. PMID:21760644.

Schmid, I., and Kazda, M. 2002. Root distribution of Norway spruce in monospecific and mixed stands on different soils. For. Ecol. Manage. 159(1-2): 37-47. doi:10.1016/S0378-1127(01)00708-3.

Schurman, J.S., Babst, F., Björklund, J., Rydval, M., Bače, R., Čada, V., et al. 2019. The climatic drivers of primary Picea forest growth along the Carpathian arc are changing under rising temperatures. Glob. Change Biol. 25: 3136-3150. doi:10.1111/gcb.14721. PMID:31166643.

Seidl, R., Thom, D., Kautz, M., Martin-Benito, D., Peltoniemi, M., Vacchiano, G., et al. 2017. Forest disturbances under climate change. Nat. Clim. Change, 7: 395-402. doi:10.1038/nclimate3303.

Smidt, S., and Herman, F. 2004. Evaluation of air pollution-related risks for Austrian mountain forests. Environ. Pollut. 130: 99-112. doi:10.1016/j.envpol. 2003.10.027.

Spiecker, H. 2000. Growth of Norway Spruce (Picea abies (L.) Karst.) under changing environmental conditions in Europe. In Spruce monocultures in central Europe: problems and prospects. Edited by E. Klimo, H. Hager, and J. Kulhavy. European Forest Institute, European Forest Institute Proceedings, No. 33. pp. 11-26.

Stroheker, S., Weiss, M., Sieber, T.N., and Bugmann, H. 2018. Ecological factors influencing Norway spruce regeneration on nurse logs in a subalpine virgin forest. Forests, 9: 120. doi:10.3390/f9030120.

Tegel, W., Seim, A., Hakelberg, D., Hoffmann, S., Panev, M., Westphal, T., and Büntgen, U. 2014. A recent growth increase of European beech (Fagus sylvatica L.) at its Mediterranean distribution limit contradicts drought stress. Eur. J. For. Res. 133: 61-71. doi:10.1007/s10342-013-0737-7.

Theurillat, J.P., and Guisan, A. 2001. Potential impact of climate change on vegetation in the European Alps: a review. Clim. Change, 50(1-2): 77-109. doi:10.1023/A:1010632015572.

Thom, D., Rammer, W., Dirnböck, T., Müller, J., Kobler, J., Katzensteiner, K., et al. 2017. The impacts of climate change and disturbance on spatiotemporal trajectories of biodiversity in a temperate forest landscape. J. Appl. Ecol. 54: 28-38. doi:10.1111/1365-2664.12644.

Tognetti, R., Lombardi, F., Lasserre, B., Cherubini, P., and Marchetti, M. 2014. Tree-ring stable isotopes reveal twentieth-century increases in water-use efficiency of Fagus sylvatica and Nothofagus spp. in Italian and Chilean mountains. PLoS One, 9: e113136. doi:10.1371/journal.pone.0113136. PMID:25398040.

Torresan, C., del Río, M., Hilmers, T., Notarangelo, M., Bielak, K., Binder, F., et al. 2020. Importance of tree species size dominance and heterogeneity on the productivity of spruce-fir-beech mountain forest stands in Europe. For. Ecol. Manage. 457: 117716. doi:10.1016/j.foreco.2019.117716.

Uhl, E., Ammer, C., Spellmann, H., Schölch, M., and Pretzsch, H. 2013. Zuwachstrend und Stressresilienz von Tanne und Fichte im Vergleich. Allg Forst und Jagdzeitung, 11-12: 278-292.

Valladares, F., and Niinemets, U. 2008. Shade tolerance, a key plant feature of complex nature and consequences. Annu. Rev. Ecol. Evol. Syst. 39: 237-257. doi:10.1146/annurev.ecolsys.39.110707.173506.

Vallet, P., and Pérot, T. 2011. Silver fir stand productivity is enhanced when mixed with Norway spruce: evidence based on large-scale inventory data and a generic modelling approach. J. Veg. Sci. 22(5): 932-942. doi:10.1111/j.16541103.2011.01288.x.

von Bertalanffy, L. 1951. Theoretische Biologie: II. Band, Stoffwechsel, Wachstum. 2nd ed. A Francke AG, Bern.

von Guttenberg, A. 1915. Wachstum und Ertrag der Fichte im Hochgebirge. Verlag Franz Deuticke, Wien und Leipzig.

Weiner, J., and Thomas, S.C. 2001. The nature of tree growth and the "age-related decline in forest productivity". Oikos, 94(2): 374-376. doi:10.1034/j.1600-0706. 2001.940219.x.

Wermelinger, B. 2004. Ecology and management of the spruce bark beetle Ips typographus - a review of recent research. For. Ecol. Manage. 202(1-3): 67-82. doi:10.1016/j.foreco.2004.07.018.

White, M.A., Running, S.W., and Thornton, P.E. 1999. The impact of growingseason length variability on carbon assimilation and evapotranspiration over 88 years in the eastern US deciduous forest. Int. J. Biometeorol. 42(3): 139-145. doi:10.1007/s004840050097.

Zang, C., Hartl-Meier, C., Dittmar, C., Rothe, A., and Menzel, A. 2014. Patterns of drought tolerance in major European temperate forest trees: climatic drivers and levels of variability. Glob. Change Biol. 20: 3767-3779. doi:10.1111/gcb. 12637. PMID:24838398.

Zeide, B. 1993. Analyses of growth equations. For. Sci. 39(3): 594-616. doi:10.1093/ forestscience/39.3.594.

Zuur, A., Ieno, E.N., Walker, N., Saveliev, A.A., and Smith, G.M. 2009. Mixed effects models and extensions in ecology with R. Springer-Verlag, New York. doi:10.1007/978-0-387-87458-6. 